\title{
5. PALEOMAGNETISM OF SOME LEG 138 SEDIMENTS: DETAILING MIOCENE MAGNETOSTRATIGRAPHY ${ }^{1}$
}

\author{
David A. Schneider ${ }^{2}$
}

\begin{abstract}
The aims of this study are twofold. First, the study tries to provide the most reliable chronology possible for two critical sections by correlating the magnetic polarity stratigraphy measured in these sediments with a newly revised geomagnetic polarity time scale. Second, this study attempts to examine in detail the nature of seven short events not included in the shipboard standard time scale, but for which abundant magnetostratigraphic evidence was obtained during the Leg.

Data presented here force some modifications of the shipboard interpretations of the magnetostratigraphy of Sites 845 and 844 on the basis of new data generated using discrete samples and from a greater appreciation of the magnetostratigraphic signature of Miocene-age short events. Those short events can be classified into two groups: those that probably reflect short, full-polarity intervals and those that more likely represent an interval of diminished geomagnetic intensity. Three of the seven events documented here correspond well with three subtle features, as seen in marine magnetic profiles, that have been newly included in the geomagnetic polarity time scale as short, full-polarity chrons. One of the seven events corresponds to a poorly defined feature of the marine magnetic record that has also been newly included in the geomagnetic polarity time scale, but which was considered of enigmatic origin. The three remaining events investigated here, although they have not been identified with features in the seafloor magnetic record, are suggested to be events of a similar nature, most likely times of anomalously low geomagnetic intensity.

In addition to the Miocene magnetostratigraphic results given, several sets of averaged paleomagnetic inclinations are presented. Although these results clearly show the effects of a residual coring overprint, they demonstrate that paleomagnetic estimates of paleolatitudes can be made which are in good general agreement with ancient site positions calculated using hot spot-based plate reconstructions.
\end{abstract}

\section{INTRODUCTION}

As with many recent legs of the Ocean Drilling Program (ODP), the fundamental contribution of paleomagnetic work on ODPLeg 138 is toward the construction of age models for the recovered sedimentary sequences. Magnetic polarity stratigraphy provides one of the most reliable and direct dating methods for deep-sea sediments (Opdyke, 1972; Harrison, 1974) by correlation of the sedimentary reversal sequence with the well-known geomagnetic polarity time scale (GPTS). The GPTS (e.g., Heirtzler et al., 1968; LaBrecque et al., 1977; Ness et al., 1980; Berggren et al., 1985; Harland et al., 1990; Cande and Kent, 1992) is derived fundamentally from magnetic profiles of seafloor spreading anomalies and has been numerically calibrated using the radiometric ages of key reversal boundaries.

Unlike the case with many other ODP legs, the task of magnetostratigraphic dating of Leg 138 sediments was largely accomplished while aboard ship. Consequently, the present study does not reproduce a large body of shipboard paleomagnetic results (Mayer, Pisias, Janecek, et al., 1992) in an attempt to cover all of the Miocene age magnetostratigraphy obtained during the leg (Fig. 1). Rather, this work focuses on two areas of magnetostratigraphy that are of particular interest: (1) refinement of the magnetostratigraphy of key sites that are critical for dating Miocene biostratigraphic events and (2) documentation of short geomagnetic events of the Miocene. The first objective is aimed at improving the ability of biostratigraphers studying these sediments to determine the ages of low-latitude speciation and extinction events of the contained microfossil groups. The second objective is directed toward documenting the character of geomagnetic polarity history over the Miocene, including short polarity intervals and intensity excursions, to improve the stratigraphic utility of the

' Pisias, N.G., Mayer, L.A., Janecek, T.R., Palmer-Julson, A., and van Andel, T.H (Eds.), 1995. Proc. ODP, Sci. Results, 138: College Station, TX (Ocean Drilling Program).

${ }^{2}$ Department of Geology and Geophysics, Woods Hole Oceanographic Institution, Woods Hole, MA 02543, U.S.A. paleomagnetic method over an interval that has often proved difficult to study with this technique.

Herein, I present in full a revised magnetostratigraphy for Site 845 derived both from shipboard and shore-based paleomagnetic data. The documentation of various short geomagnetic events of the Miocene draws from this site as well as a number of others. The stratigraphic utility of these short geomagnetic events is demonstrated by a revision to the shipboard magnetostratigraphic interpretation of Site 844 , suggested by these newly recognized details of the Miocene geomagnetic field.

The geomagnetic polarity time scale adopted for this study is that of Cande and Kent (1992), herein termed CK92. This is a significant revision from the time scale presented in Berggren et al. (1985), which was used for shipboard work. The new time scale is probably of greater accuracy in its assignment of numerical ages, but more significantly, it captures additional character of the geomagnetic polarity reversal sequence and can be more readily compared with the detailed magnetostratigraphy recorded in these sediments.

\section{MAGNETOSTRATIGRAPHY OF SITE 845}

\section{General Considerations}

Site 845 provides a rare example of a continuous mid-Miocene to mid-Pliocene magnetostratigraphy from a low-latitude site. Because sediments from Site 845 also contain reasonably well-preserved microfossil assemblages, these paleomagnetic results are of particular value in that they allow the calibration of low-latitude biostratigraphic events against the magnetic polarity time scale. In this section I will detail the magnetostratigraphy obtained from sediments taken from about 50 to $230 \mathrm{~m}$ composite depth (mcd), the base of coring with the advanced piston corer (APC). Results from above $50 \mathrm{mcd}$ are not presented because the initial shipboard measurements indicated only a noisy, lowlevel paleomagnetic signal over this uppermost interval. Shipboard results did, however, clearly show an abrupt transition to stronger magnetization intensities below this level and so from about 50 to $230 \mathrm{mcd}$ magnetostratigraphic interpretation was possible. In developing a mag- 


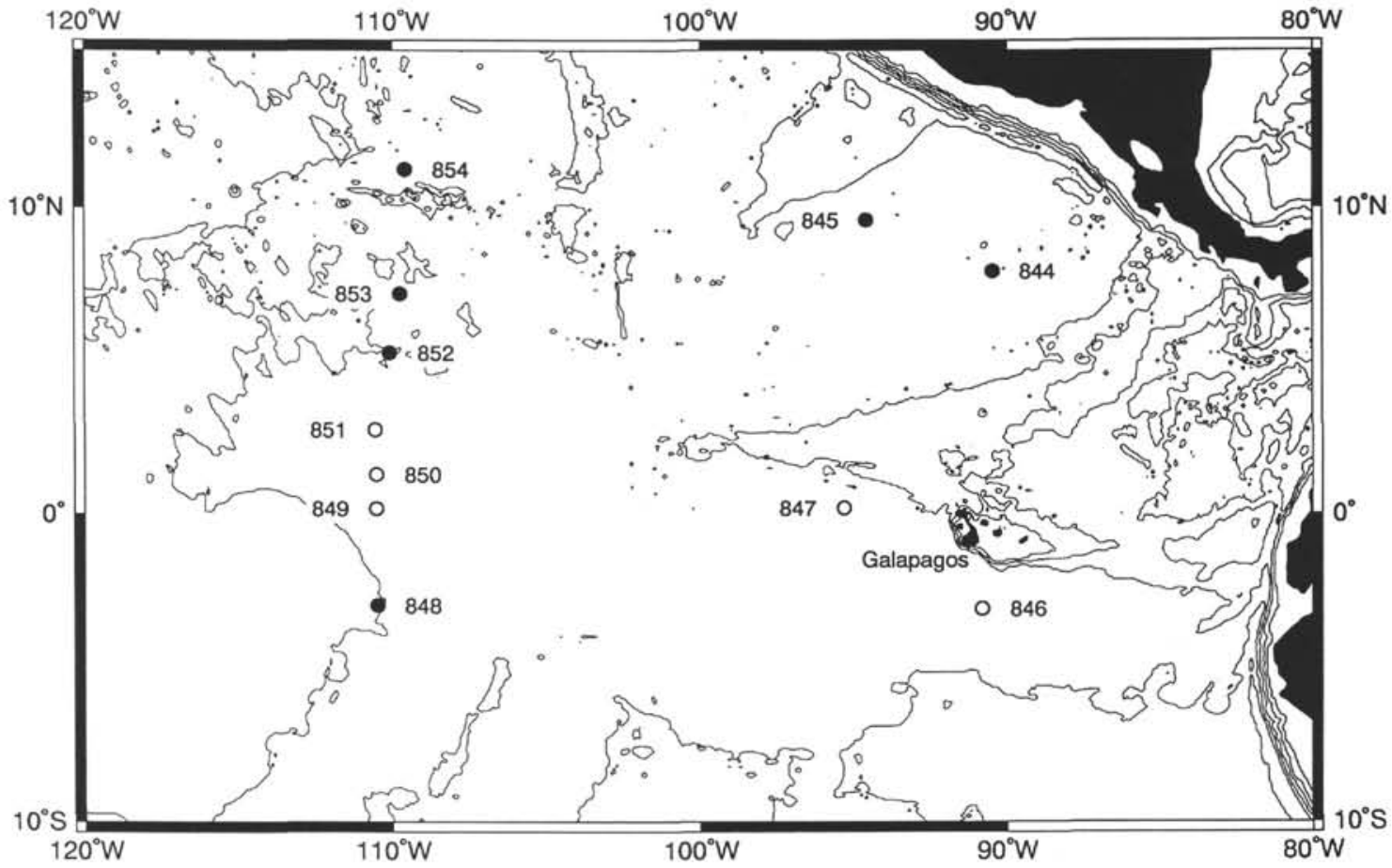

Figure 1. Location of Leg 138 sites in the eastern equatorial Pacific. Solid points show drill sites where the measurement of the sediments aboard ship revealed Miocene-age magnetostratigraphy; open points show sites without significant Miocene-age magnetostratigraphic results. This study draws from results obtained at Site $844\left(7^{\circ} 55^{\prime} \mathrm{N}, 90^{\circ} 29^{\prime} \mathrm{W}\right)$, Site $845\left(9^{\circ} 35^{\prime} \mathrm{N}, 94^{\circ} 35^{\prime} \mathrm{W}\right)$, Site $848\left(3^{\circ} 00^{\prime} \mathrm{S}, 110^{\circ} 29^{\prime} \mathrm{W}\right)$, Site $852\left(5^{\circ} 18^{\prime} \mathrm{N}, 110^{\circ} 5^{\prime} \mathrm{W}\right)$ and Site $854\left(11^{\circ} 13^{\prime} \mathrm{N}, 109^{\circ} 36^{\prime} \mathrm{W}\right)$. Contour interval $=1000 \mathrm{~m}$.

netostratigraphic interpretation, I have combined shipboard passthrough magnetometer results with detailed shore-based measurements of discrete samples to best reveal the polarity reversal sequence (Table 1).

The following description of magnetostratigraphy from Site 845 is divided into three parts corresponding, roughly, to the middle Miocene, late Miocene, and Pliocene portions of the section. The paleomagnetic data for Pliocene (Fig. 2) and late Miocene (Fig. 3) are exclusively from shipboard pass-through magnetometer measurements which revealed a strong and consistent magnetization. The shipboard results for portions of the middle Miocene interval were, however, less satisfactory and so the relevant cores (Cores 138-845A$16 \mathrm{H}$ to $138-845 \mathrm{~A}-22 \mathrm{H}$ and $138-845 \mathrm{~B}-16 \mathrm{H}$ to $138-845 \mathrm{~B}-21 \mathrm{H})$ were completely remeasured using discrete samples (Fig. 4). Although the discrete sample results, generated each $20 \mathrm{~cm}$, provide a record that is somewhat coarser than that of the pass-through magnetometer (which inherently averages the magnetization over about 10 to 15 $\mathrm{cm}$ ), the quality of the data is significantly improved for several of the remeasured cores. Thus the magnetostratigraphic sequence determined for the middle Miocene section can be correlated to the GPTS much more convincingly than could be done otherwise from the shipboard measurements.

\section{Determination of Polarity Sense}

Most of the Site 845 cores considered in this section show reversals by abrupt $180^{\circ}$ (or near $180^{\circ}$ ) changes in declination; however, corresponding inclination changes are seldom as obvious. This lack of inclination signal is partly a function of the low site latitude (the present latitude is $10^{\circ}$ ) and partly a result of the obscuring effects of a ubiquitous, vertically directed coring overprint (Mayer, Pisias, Janecek, et al., 1992), which is commonly only incompletely removed by demagnetization (Fig. 5). Thus, paleomagnetic measurements that can readily resolve zones of alternate polarity do not necessarily contain enough information to determine which set of magnetozones is normally magnetized and which is reversely magnetized. This long-standing problem with paleomagnetic work on low-latitude cores was anticipated during Leg 138 and the effort was made to overcome it using the Eastman-Whipstock multi-shot photographic orientation device on each of the APC cores taken.

Although azimuthal correction (based on the photographic orientation tool) appears reasonably consistent with the paleomagnetic directions measured in most of the Leg $138 \mathrm{APC}$ cores, there are many cases where photographic orientation clearly failed to give reasonable results: in some instances, the photographic determination of north was $90^{\circ}$ from the dominant paleomagnetic declinations. In some other examples where the polarity sense could be determined from inclination changes, the photographic determination of north was nearly $180^{\circ}$ from the paleomagnetic declination of the normally magnetized intervals.

For reasons that remain unclear, the photographic orientations obtained at Hole 845B are much more erratic than was typical of most other holes taken during the leg. Thus the photographic orientation information for Site 845 has been used only as a loose guide for checking the polarity interpretation. (Orientation results are shown in Figures 2,3, and 4 as the predicted declination, in core coordinates, of the photographically determined north direction.) To determine polarity sense for the interpretation, I have relied on those levels that show distinct inclination changes at reversal boundaries. As mentioned, the vertical component of the primary magnetization at this low-latitude site is small and is usually obscured by the pervasive vertical (upward) overprint; however, in many instances inclination changes at reversal boundaries remain quite obvious. Such clear changes in the sign of the inclination determine the polarity sense for the given core if the hemisphere of the ancient site position is known. Despite some degree of tectonic complexity in the area, it is reasonable to presume that Site 845 has always been in the Northern Hemisphere. Because this premise is critical to the polarity interpretation, it is worth considering in some detail. 
Table 1. Reversal boundary depths, Site 845 .

\begin{tabular}{|c|c|c|c|c|}
\hline $\begin{array}{l}\text { Core, section } \\
\text { interval }(\mathrm{cm})\end{array}$ & $\begin{array}{l}\text { Depth } \\
\text { (mbsf) }\end{array}$ & $\begin{array}{l}\text { Depth } \\
\text { (mcd) }\end{array}$ & Interpretation & $\begin{array}{l}\text { Age } \\
\text { (Ma) }\end{array}$ \\
\hline \multicolumn{5}{|l|}{$138-845 \mathrm{~A}=$} \\
\hline & 49.80 & 53.88 & C2An.In/C2An.Ir & 3.0 \\
\hline $6 \mathrm{H}-4,80$ & 50.90 & 54.98 & C2An. Ir/C2An.2n & 3,1 \\
\hline $6 \mathrm{H}-5,30$ & 51.90 & 55.98 & $\mathrm{C} 2 \mathrm{An} \cdot 2 \mathrm{n} / \mathrm{C} 2 \mathrm{An} \cdot 2 \mathrm{r}$. & 3.2 . \\
\hline $6 \mathrm{H}-6,20$ & 53.30 & 57.38 & $\mathrm{C} 2 \mathrm{An} \cdot 2 \mathrm{r} / \mathrm{C} 2 \mathrm{An} .3 \mathrm{n}$ & 3.3. \\
\hline $7 \mathrm{H}-4,110$ & 60.70 & 65.56 & $\mathrm{C} 2 \mathrm{Ar} / \mathrm{C} 3 \mathrm{n} . \mathrm{In}$ & 4.03 \\
\hline $7 \mathrm{H}-5,110$ & 62.20 & 67.06 & $\mathrm{C} 3 \mathrm{n} . \ln / \mathrm{C} 3 \mathrm{n} . \mathrm{Ir}$ & 4.1 \\
\hline $7 \mathrm{H}-6,100$ & 63.60 & 68.46 & C $3 n .1 r / C 3 n .2 n$ & 4.2 \\
\hline $8 \mathrm{H}-1,70$ & 65.30 & 71.60 & $\mathrm{C} 3 n .2 \mathrm{r} / \mathrm{C} 3 \mathrm{n} \cdot 3 \mathrm{n}$ & 4.61 \\
\hline $8 \mathrm{H}-1.115$ & 65.75 & 72.05 & $\mathrm{C} 3 \mathrm{n} .3 \mathrm{n} / \mathrm{C} 3 \mathrm{n} .3 \mathrm{r}$ & 4.6 \\
\hline $8 \mathrm{H}-2,90$ & 67.00 & 73.30 & $\mathrm{C} 3 \mathrm{n} \cdot 3 \mathrm{r} / \mathrm{C} 3 \mathrm{n} \cdot 4 \mathrm{n}$ & 4.81 \\
\hline $8 \mathrm{H}-4,60$ & 69.70 & 76.00 & $\mathrm{C} 3 \mathrm{n} \cdot 4 \mathrm{n} / \mathrm{C} 3 \mathrm{r}$ & 5.0 \\
\hline $9 \mathrm{H}-4,90$ & 79.50 & 87.51 & $\mathrm{C} 3 \mathrm{r} / \mathrm{C} 3 \mathrm{An} \cdot \mathrm{In}$ & 5.70 \\
\hline $9 \mathrm{H}-6,60$ & 82.20 & 90.21 & C3An.In/C3An.Ir & 5.94 \\
\hline $10 \mathrm{H}-3,120$ & 87.80 & 96.28 & $\mathrm{C} 3 \mathrm{An} \cdot 2 \mathrm{n} / \mathrm{C} 3 \mathrm{Ar}$ & 6.37 \\
\hline $10 \mathrm{H}-7,10$ & 92.70 & 101.18 & $\mathrm{C} 3 \mathrm{Ar} / \mathrm{C} 3 \mathrm{Bn}$ & 6.7 \\
\hline $11 \mathrm{H}-1,85$ & 93.95 & 103.71 & $\mathrm{C} 3 \mathrm{Br} . \mathrm{Ir} / \mathrm{C} 3 \mathrm{Br} . \mathrm{In}$ & 6.94 \\
\hline $11 \mathrm{H}-2,10$ & 94.70 & 104.46 & $\mathrm{C} 3 \mathrm{Br} . \mathrm{In} / \mathrm{C} 3 \mathrm{Br} .2 \mathrm{r}$ & 6.98 \\
\hline $11 \mathrm{H}-3,100$ & 97.10 & 106.86 & $\mathrm{C} 3 \mathrm{Br} \cdot 2 \mathrm{r} / \mathrm{C} 3 \mathrm{~B}$ & 7.1 \\
\hline $1 \mathrm{H}-4,10$ & 97.70 & 107.46 & $\mathrm{C} 3 \mathrm{Br} .2 \mathrm{n} / \mathrm{C} 3 \mathrm{Br} .3 \mathrm{r}$ & 7.18 \\
\hline $11 \mathrm{H}-4,70$ & 98.30 & 108.06 & $\mathrm{C} 3 \mathrm{Br} .3 \mathrm{r} / \mathrm{C} 4 \mathrm{n} . \mathrm{In}$ & 7.24 \\
\hline $11 \mathrm{H}-5,125$ & 100.35 & 110.11 & $\mathrm{C} 4 \mathrm{n} . \mathrm{In} / \mathrm{C} 4 \mathrm{n} . \mathrm{Ir}$ & 7.37 \\
\hline $11 \mathrm{H}-6.65$ & 101.25 & 111.01 & $\mathrm{C} 4 \mathrm{n} .2 \mathrm{n}$ & 7.46 \\
\hline $12 \mathrm{H}-4.85$ & 107.95 & 119.28 & $\mathrm{C} 4 \mathrm{n} .2 \mathrm{n} / \mathrm{C} 4 \mathrm{r} .1 \mathrm{r}$ & 7.85 \\
\hline $12 \mathrm{H}-5,75$ & 109.35 & 120.68 & $C 4 r . \mid r-I$ (center) & \\
\hline $12 \mathrm{H}-6,40$ & 110.50 & 121.83 & $\mathrm{C} 4 \mathrm{r} .1 \mathrm{r} / \mathrm{C} 4 \mathrm{r} .1 \mathrm{n}$ & 8.04 \\
\hline $12 \mathrm{H}-6,70$ & 110.80 & 122.13 & $\mathrm{C} 4 \mathrm{r} . \mathrm{In} / \mathrm{C} 4 \mathrm{r} .2 \mathrm{r}$ & 8.07 \\
\hline $13 \mathrm{H}-3,25$ & 115.35 & 127.96 & C4r.2r-l (term.) & 8.46 \\
\hline $13 \mathrm{H}-3,95$ & 116.05 & 128.66 & C4r.2r-1 (onset) & 8.47 \\
\hline $13 \mathrm{H}-4,50$ & 117.10 & 129.71 & $\mathrm{C} 4 \mathrm{r} \cdot 2 \mathrm{r} / \mathrm{C} 4 \mathrm{An}$ & 8.52 \\
\hline $14 \mathrm{H}-1,110$ & 122.70 & 136.68 & $\mathrm{C} 4 \mathrm{An} / \mathrm{C} 4 \mathrm{Ar} .1 \mathrm{r}$ & 8.86 \\
\hline $14 \mathrm{H}-2,130$ & 124.40 & 138.38 & C4Ar.Ir-I (center) & $?$ \\
\hline $14 \mathrm{H}-3,140$ & 126.00 & 139.98 & C4Ar.Ir/C4Ar.In & 9.06 \\
\hline $14 \mathrm{H}-4,135$ & 127.45 & 141.43 & C 4 Ar. In/C4Ar.2r & 9.14 \\
\hline $14 \mathrm{H}-7,50$ & 131.10 & 145.08 & $\mathrm{C} 4 \mathrm{Ar} .2 \mathrm{r} / \mathrm{C} 4 \mathrm{Ar} \cdot 2 \mathrm{n}$ & 9.4 \\
\hline $15 \mathrm{H}-\mathrm{I} .90$ & 132.00 & 147.86 & C4Ar.3r/C5n.In & 9.5 \\
\hline $15 \mathrm{H}-3,25$ & 134.35 & 150.21 & C.5n.In/C5n.Ir & 9.73 \\
\hline $15 \mathrm{H}-3,80$ & 134.90 & 150.76 & C5n.Ir/C. $5 n .2 n$ & 9.77 \\
\hline $16 \mathrm{H}-5,60$ & 147.20 & 164.93 & C5n.2n/C5r.1r & 10.8 \\
\hline $16 \mathrm{H}-6,18$ & 148.28 & 166.01 & C5r.1r/C5r.In & 10.9 \\
\hline $16 \mathrm{H}-6.77$ & 148.87 & 166.60 & $\mathrm{C} 5 \mathrm{r} .1 \mathrm{n} / \mathrm{C} 5 \mathrm{r} .2 \mathrm{r}$ & 10.98 \\
\hline $17 \mathrm{H}-4.76$ & 155.36 & 174.17 & $\mathrm{C} 5 \mathrm{r} .2 \mathrm{r} / \mathrm{C} 5 \mathrm{r} .2 \mathrm{n}$ & 11.3 \\
\hline $17 \mathrm{H}-5,86$ & 156.96 & 175.77 & C5r.2n/C5r.3r & 11.4 \\
\hline $18 \mathrm{H}-4,35$ & 164.45 & 183.73 & C5r.3r/C5An.In & 11.8 \\
\hline $18 \mathrm{H}-6,76$ & 167.86 & 187.14 & C5An.In/C5An.1r & 12.00 \\
\hline $20 \mathrm{H}-3,97$ & 182.57 & 204.90 & C5Ar.1r/C5Ar.1n & \\
\hline $20 \mathrm{H}-4,86$ & 183.96 & 206.29 & C5Ar. $1 \mathrm{n} / \mathrm{C} 5 \mathrm{Ar} .2 \mathrm{r}$ & 12.6 \\
\hline $20 \mathrm{H}-5,115$ & 185.75 & 208.08 & C5Ar.2r/C5Ar.2n & 12.7 \\
\hline $20 \mathrm{H}-6,131$ & 187.41 & 209.74 & $\mathrm{C} 5 \mathrm{Ar} .2 \mathrm{n} / \mathrm{C} 5 \mathrm{Ar} .3 \mathrm{r}$ & 12.7 \\
\hline $21 \mathrm{H}-3,140$ & 192.50 & 215.73 & C5Ar.3r/C5AAn & \\
\hline $21 \mathrm{H}-6,115$ & 196.75 & 219.98 & C5AAn/C5AAr & \\
\hline $22 \mathrm{H}-3.79$ & 201.39 & 226.62 & $\mathrm{C} 5 \mathrm{AAr} / \mathrm{C} 5 \mathrm{ABn}$ & 13.2 \\
\hline
\end{tabular}

Site 845 is located in the vicinity of what may be a fossil spreading center, within a series of seafloor-spreading anomalies that have not been tied to the magnetic polarity time scale (Klitgord and Mammerickx, 1982). This makes exact plate reconstruction impossible; however, one can easily examine the extreme case by assuming that all the seafloor between Site 845 and the East Pacific Rise is younger than this site's basement age. Using the general trend of fracture zones, one can estimate the location of a conjugate point to the site on the Pacific Plate. This is in the vicinity of $5^{\circ} \mathrm{N}, 110^{\circ} \mathrm{W}$. Because this conjugate point was formed at the same time and place as Site 845 , it shared a common latitude at the time of crustal formation, about $17 \mathrm{Ma}$ (Mayer, Pisias, Janecek, et al., 1992). Site 845 has since moved northeastward relative to its conjugate point on the Pacific Plate; thus, the paleolatitude of the conjugate point provides an extreme southern estimate for the paleolatitude of Site 845 . It remains only to specify the absolute reference frame for backtracking the conjugate point. For this calculation, I have used Pacific/hot-spot Euler poles of Cox and Engebretson (1985), which indicate that the conjugate point was at $3^{\circ} \mathrm{N}$ at $10 \mathrm{Ma}$ and at $2^{\circ} \mathrm{N}$ at $20 \mathrm{Ma}$. Note that these results are relatively insensitive to the estimated longitude of the conjugate point and thus strongly argue that Site 845 was never in the Southern Hemisphere.

\begin{tabular}{|c|c|c|c|c|}
\hline $\begin{array}{l}\text { Core, section } \\
\text { interval }(\mathrm{cm})\end{array}$ & $\begin{array}{l}\text { Depth } \\
\text { (mbsf) }\end{array}$ & $\begin{array}{l}\text { Depth } \\
\text { (mcd) }\end{array}$ & Interpretation & $\begin{array}{l}\text { Age } \\
(\mathrm{Ma})\end{array}$ \\
\hline \multicolumn{5}{|l|}{ 138-845B- } \\
\hline $6 \mathrm{H}-2,105$ & 53.15 & 59.88 & $\mathrm{C} 2 \mathrm{An} \cdot 3 \mathrm{n} / \mathrm{C} 2 \mathrm{Ar}$ & 3.553 \\
\hline $6 \mathrm{H}-6,70$ & 58.80 & 65.53 & $\mathrm{C} 2 \mathrm{Ar} / \mathrm{C} 3 \mathrm{n} .1 \mathrm{n}$ & 4.033 \\
\hline $7 \mathrm{H}-2,35$ & 61.95 & 68.56 & $\mathrm{C} 3 \mathrm{n} . \mathrm{Ir} / \mathrm{C} 3 \mathrm{n} .2 \mathrm{n}$ & 4.265 \\
\hline $7 \mathrm{H}-3,5$ & 63.15 & 69.76 & $\mathrm{C} 3 n .2 n / C 3 n .2 r$ & 4.432 \\
\hline $7 \mathrm{H}-4,35$ & 64.95 & 71.56 & C 3 n. 2 r/C 3 n. $3 n$ & 4.611 \\
\hline $7 \mathrm{H}=4,85$ & 65.45 & 72.06 & C $3 n .3 n / C 3 n .3 r$ & 4.694 \\
\hline $7 \mathrm{H}-5,55$ & 66.65 & 73.26 & $\mathrm{C} 3 \mathrm{n} .3 \mathrm{r} / \mathrm{C} 3 \mathrm{n} \cdot \mathrm{4n}$ & 4.812 \\
\hline $7 \mathrm{H}-7,25$ & 69.35 & 75.96 & $\mathrm{C} 3 \mathrm{n} .4 \mathrm{n} / \mathrm{C} 3 \mathrm{r}$ & 5.046 \\
\hline $8 \mathrm{H}-7,50$ & 79.10 & 87.48 & $\mathrm{C} 3 \mathrm{r} / \mathrm{C} 3 \mathrm{An} . \mathrm{In}$ & 5.705 \\
\hline $9 \mathrm{H}-2,75$ & 81.35 & 90.21 & C $3 \mathrm{An} .1 \mathrm{n} / \mathrm{C} 3 \mathrm{An} .1 \mathrm{r}$ & 5.946 \\
\hline $9 \mathrm{H}-4,5$ & 83.65 & 92.51 & C 3 An.Ir/C3An.2n & 6.078 \\
\hline $9 \mathrm{H}-6,85$ & 87.45 & 96.31 & C $3 \mathrm{An} .2 \mathrm{n} / \mathrm{C} 3 \mathrm{Ar}$ & 3.376 \\
\hline $10 \mathrm{H}-2,125$ & 91.35 & 101.68 & $\mathrm{C} 3 \mathrm{Ar} / \mathrm{C} 3 \mathrm{Bn}$ & 6.744 \\
\hline $10 \mathrm{H}-3,125$ & 92.85 & 103.18 & $\mathrm{C} 3 \mathrm{Bn} / \mathrm{C} 3 \mathrm{Br} . \mathrm{Ir}$ & 6.901 \\
\hline $10 \mathrm{H}-4,50$ & 93.60 & 103.93 & $\mathrm{C} 3 \mathrm{Br} .1 \mathrm{r} / \mathrm{C} 3 \mathrm{Br}$. In & 6.946 \\
\hline $10 \mathrm{H}-4,105$ & 94.15 & 104.48 & $\mathrm{C} 3 \mathrm{Br} . \mathrm{In} / \mathrm{C} 3 \mathrm{Br} .2 \mathrm{r}$ & 6.981 \\
\hline $10 \mathrm{H}-6,30$ & 96.40 & 106.73 & $\mathrm{C} 3 \mathrm{Br} .2 \mathrm{r} / \mathrm{C} 3 \mathrm{Br} .2 \mathrm{n}$ & 7.153 \\
\hline $10 \mathrm{H}-6.85$ & 96.95 & 107.28 & $\mathrm{C} 3 \mathrm{Br} .2 \mathrm{n} / \mathrm{C} 3 \mathrm{Br} .3 \mathrm{r}$ & 7.187 \\
\hline $10 \mathrm{H}-7,5$ & 97.65 & 107,98 & $\mathrm{C} 3 \mathrm{Br} .3 \mathrm{r} / \mathrm{C} 4 \mathrm{n} . \mathrm{In}$ & 7.245 \\
\hline $11 \mathrm{H}-7,10$ & 107.20 & 119.31 & $\mathrm{C} 4 \mathrm{n} .2 \mathrm{n} / \mathrm{C} 4 \mathrm{r} .1 \mathrm{r}$ & 7.892 \\
\hline $12 \mathrm{H}-2,35$ & 109.45 & 122.43 & $\mathrm{C} 4 \mathrm{r} .1 \mathrm{n} / \mathrm{C} 4 \mathrm{r} .2 \mathrm{r}$ & 8.079 \\
\hline $12 \mathrm{H}-6,10$ & 115.20 & 128.18 & C $4 r .2 r-1$ (term.) & 8.463 \\
\hline $12 \mathrm{H}-6,50$ & 115.60 & 128.58 & $C 4 r .2 r-1$ (onset) & 8.479 \\
\hline $12 \mathrm{H}-7,20$ & 116.80 & 129.78 & $\mathrm{C} 4 \mathrm{r} .2 \mathrm{r} / \mathrm{C} 4 \mathrm{An}$ & 8.529 \\
\hline $13 \mathrm{H}-4,45$ & 122.05 & 136.81 & $\mathrm{C} 4 \mathrm{An} / \mathrm{C} 4 \mathrm{Ar} .1 \mathrm{r}$ & 8.861 \\
\hline $13 \mathrm{H}-5,60$ & 123.70 & 138.46 & C4Ar.Ir-I (center) & \\
\hline $13 \mathrm{H}-6,65$ & 125.25 & 140.01 & C4Ar. Ir/C4Ar. In & 9.069 \\
\hline $14 \mathrm{H}-2,55$ & 128.65 & 145.05 & C 4 Ar. 2 r/C 4 Ar. $2 n$ & 9.428 \\
\hline $14 \mathrm{H}-3,70$ & 130.30 & 146.70 & $\mathrm{C} 4 \mathrm{Ar} .2 \mathrm{n} / \mathrm{C} 4 \mathrm{Ar} \cdot 3 \mathrm{r}$ & 9.491 \\
\hline $14 \mathrm{H}-4,25$ & 131.35 & 147.75 & C4Ar.3r/C5n.1n & 9.592 \\
\hline $14 \mathrm{H}-5,135$ & 133.95 & 150.35 & C $5 n . \operatorname{In} / \mathrm{C} 5 \mathrm{n} .1 \mathrm{r}$ & 9.730 \\
\hline $14 \mathrm{H}-6,30$ & 134.40 & 150.80 & C.5n. Ir/C5n.2n & 9.777 \\
\hline $16 \mathrm{H}-1.75$ & 146.35 & 166.05 & C.5r.Ir/C5r.In & 10.940 \\
\hline $16 \mathrm{H}-2,15$ & 147.25 & 166.95 & C5r.1n/C5r.2r & 10.989 \\
\hline $16 \mathrm{H}-2,136$ & 148.46 & 168.16 & C5r.2r-1 (term.) & \\
\hline $16 \mathrm{H}-3,65$ & 149.25 & 168.95 & C5r.2r-I (onset) & \\
\hline $16 \mathrm{H}-6,135$ & 154.45 & 174.15 & C $5 r .2 r / C 5 r .2 n$ & 11.378 \\
\hline $17 \mathrm{H}-6,115$ & 163.75 & 183.55 & C5r3.r/C5An.1n & 11.852 \\
\hline $18 \mathrm{H}-2,55$ & 166.65 & 186.95 & C5An.In/C5An.Ir & 12.000 \\
\hline $18 \mathrm{H}-4,15$ & 169.25 & 189.55 & C5An. Ir/C5An.2n & 12.108 \\
\hline $20 \mathrm{H}-1,85$ & 184.45 & 206.25 & C5Ar.1n/C5Ar. $2 r$ & 12.649 \\
\hline $20 \mathrm{H}-2,125$ & 186.35 & 208.15 & C5Ar.2r/C5Ar.2n & 12.718 \\
\hline $20 \mathrm{H}-3,100$ & 187.60 & 209.40 & C 5 Ar. $2 n / C 5 A r .3 r$ & 12.764 \\
\hline $21 \mathrm{H}-\mathrm{I}, 95$ & 194.05 & 215.35 & C5Ar.3r/C5AAn & 12.941 \\
\hline $21 \mathrm{H}-4,125$ & 198.85 & 220.15 & C5AAn/C5AAr & 13.094 \\
\hline
\end{tabular}

Note: Interval given is measured level nearest the reversal. Associated errors are normally 10 to $15 \mathrm{~cm}$, except in cores numbered 16 or greater (determined from discrete samples) where they are \pm 20 . The magnetic polarity time scale and nomenclature are from Cande and Kent (1992). Italics denote cryptochrons identified by Cande and Kent or by this study.

This conclusion from the plate tectonic history of the site simplifies the determination of polarity sense from inclination; unfortunately, the primary inclination signal is not apparent for many of the cores. Nevertheless, polarity sense can usually be transferred from the few clear cases to cores in the adjacent hole that stratigraphically overlap. Indeed, polarity assignment can logically be transferred back and forth between overlapping cores in the two holes, extending the assignment of polarity sense up and down the section. This method of polarity assignment obviously relies heavily on consistent stratigraphic overlapping between adjacent holes and on the accurate determination of that overlapping; fortunately, such stratigraphic control was routinely obtained.

One of the hallmarks of Leg 138 was the emphasis placed on maintaining stratigraphic overlapping using real-time measurements (of sediment density, color reflectance, and magnetic susceptibility) and on adjusting coring depths appropriately (Hagelberg et al., 1992). Refined values of stratigraphic overlapping were determined aboard ship, and these were incorporated into a composite depth model for each site. These depth models have proved to be consistently accurate, as demonstrated, for example, by the paleomagnetic records themselves, which serve as one means of independently checking the composite 


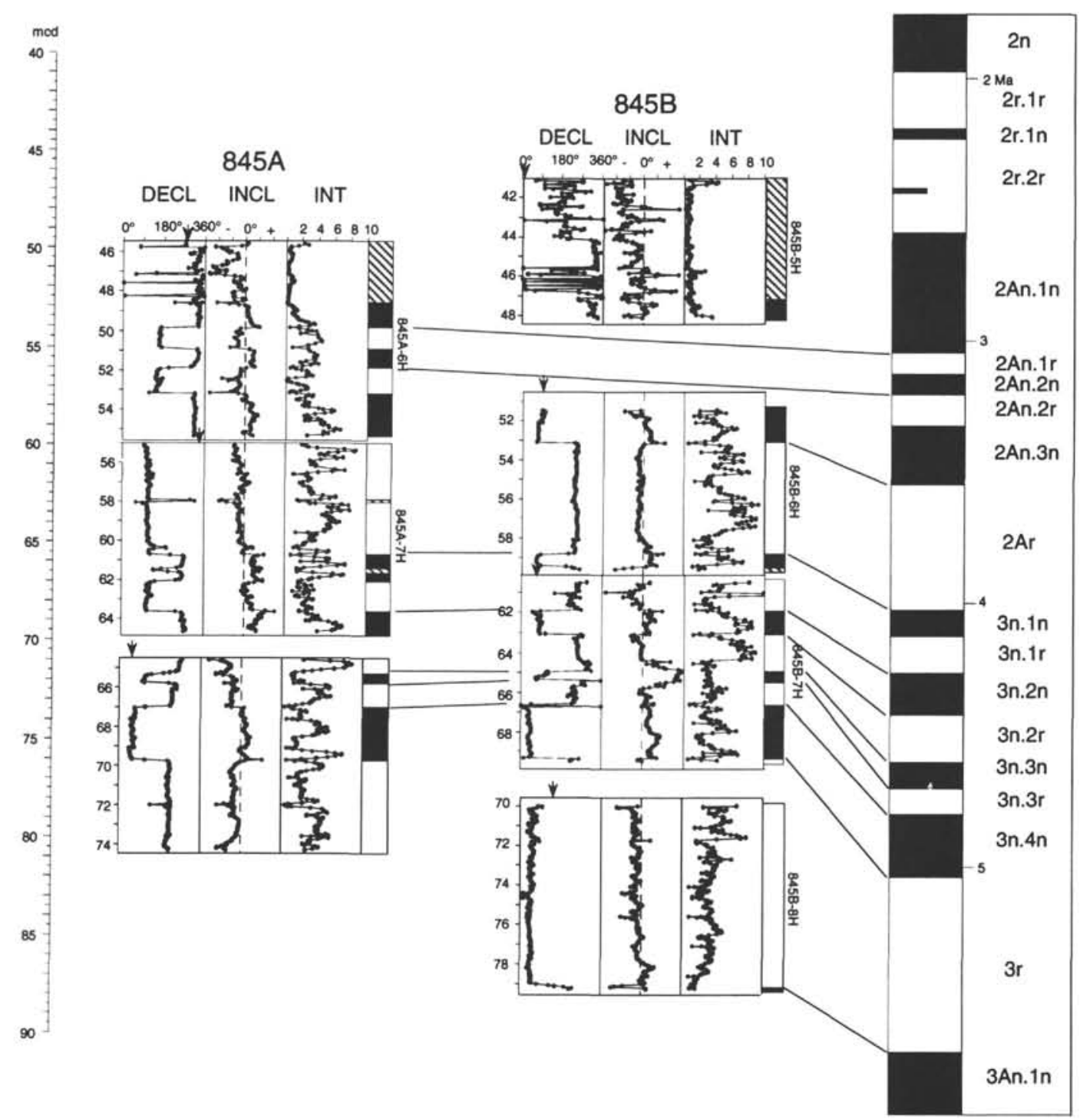

Figure 2. Magnetostratigraphy of the Pliocene section of Site 845. Each panel of three plots (declination, inclination, intensity) corresponds to one APC core and is placed vertically at the appropriate composite depth. The depth scale at left indicates meters composite depth (mcd); the depth scale attached to each core panel shows nominal meters below seafloor (mbsf). Declinations are shown with respect to the double fiducial line on the core liner. The downward-pointing arrow on the declination panel for each core shows the predicted direction of geographic north according to the photographic orientation tool. Inclination scale ranges from $-90^{\circ}$ to $+90^{\circ}$. Intensity scale indicates milliamps per meter. Polarity interpretation is shown by the bar attached to the right of each core panel: black indicates normal polarity; white indicates reversed polarity, hachured zones indicate that no polarity was assigned. Geomagnetic polarity time scale (right) is from Cande and Kent (1992). Black indicates normal polarity intervals; white indicates reverse polarity intervals. Bars spanning half the polarity column are used to show short cryptochrons of the CK92 time scale. Paleomagnetic data are from shipboard pass-through magnetometer measurements made after 15-mT AF demagnetization.

depths: virtually all paleomagnetic reversals measured in adjacent holes at the various sites cored during the leg fall at the same composite depth, or, at most, are displaced only a few tens of centimeters.

There remains one other possible method of polarity determination potentially available from the consideration of the direction of the low-coercivity overprint: a viscous overprint, if it can be isolated, can be used as an indication of north. The ability to isolate such an overprint for Leg 138 sediments is, however, severely compromised by the presence of a coring overprint (directed steeply upward) in nearly all samples. Nevertheless, by assuming this coring overprint contributes only a vertical magnetization, the declination of the low-coercivity component should reflect any residual viscous overprint. Indeed, the declination of the low-coercivity component seen in most samples from Site 845 is generally consistent with the polarity interpretation adopted independently: in reversely magnetized levels the overprint declination is often distinctly opposite that of the high-coercivity (primary) component. Unfortunately, polarity determination by this method alone would likely not be particularly reliable because the overprint declination can appear at odds with expectation based on inclination/ transfer or photographic orientation. The most troubling inconsistency noted is with Core 138-845A-22H. For this core, I am forced to discount any suggestion based on overprint directions and have maintained interpretation of polarity sense according to the transfer from the stratigraphically overlapping portion of the adjacent hole (Core $138-845 \mathrm{~B}-21 \mathrm{H})$. The alternative hypothesis would require that the stratigraphic overlap seen in susceptibility, density and color is spuri- 


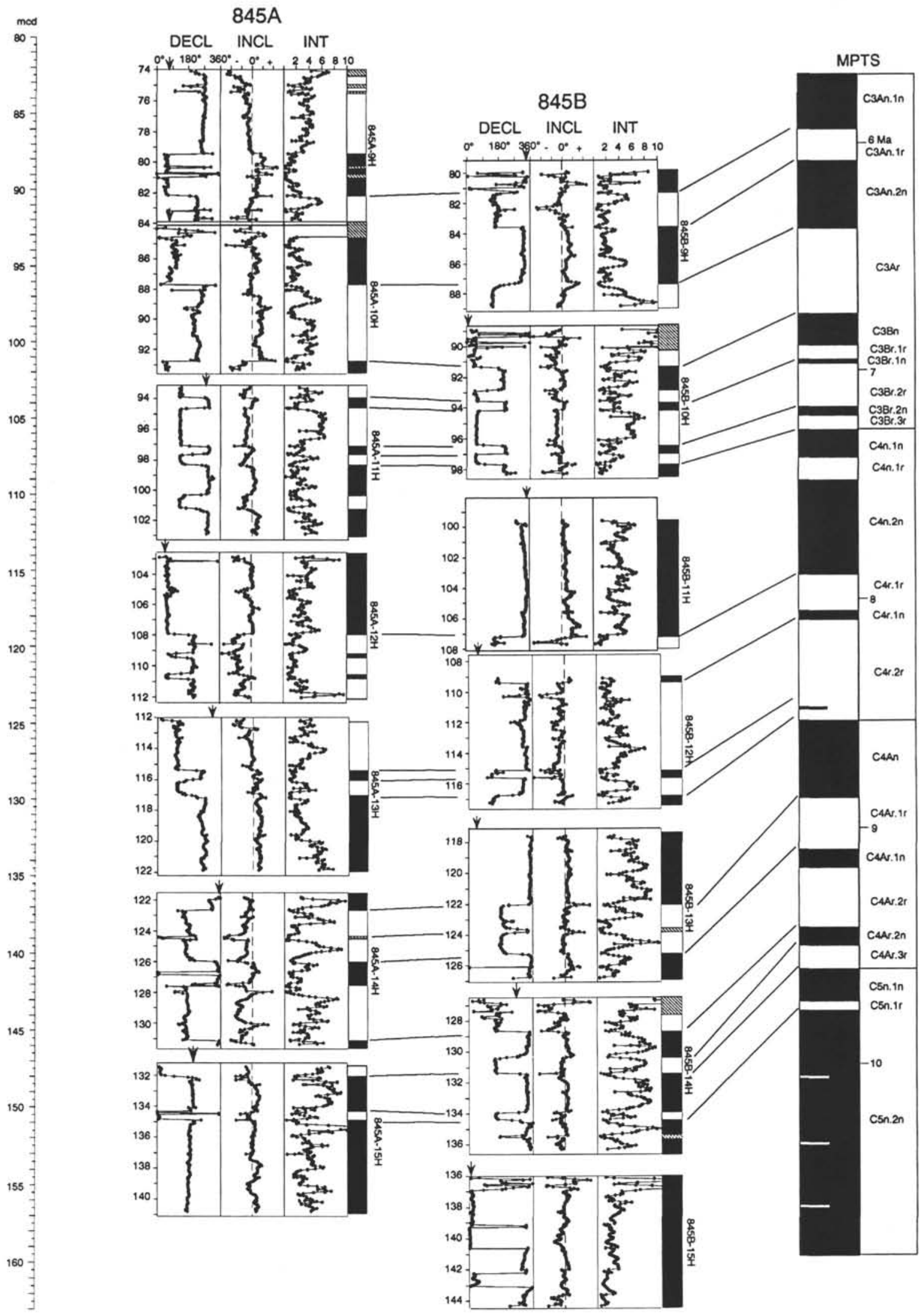

Figure 3. Magnetostratigraphy of the upper Miocene section of Site 845. Plotting conventions are as in Figure 1. Paleomagnetic data are from shipboard pass-through magnetometer measurements made after $15-\mathrm{mT}$ AF demagnetization. Note that high-intensity values near the core tops (most likely a result of contamination from pipe rust scale) are not shown. 


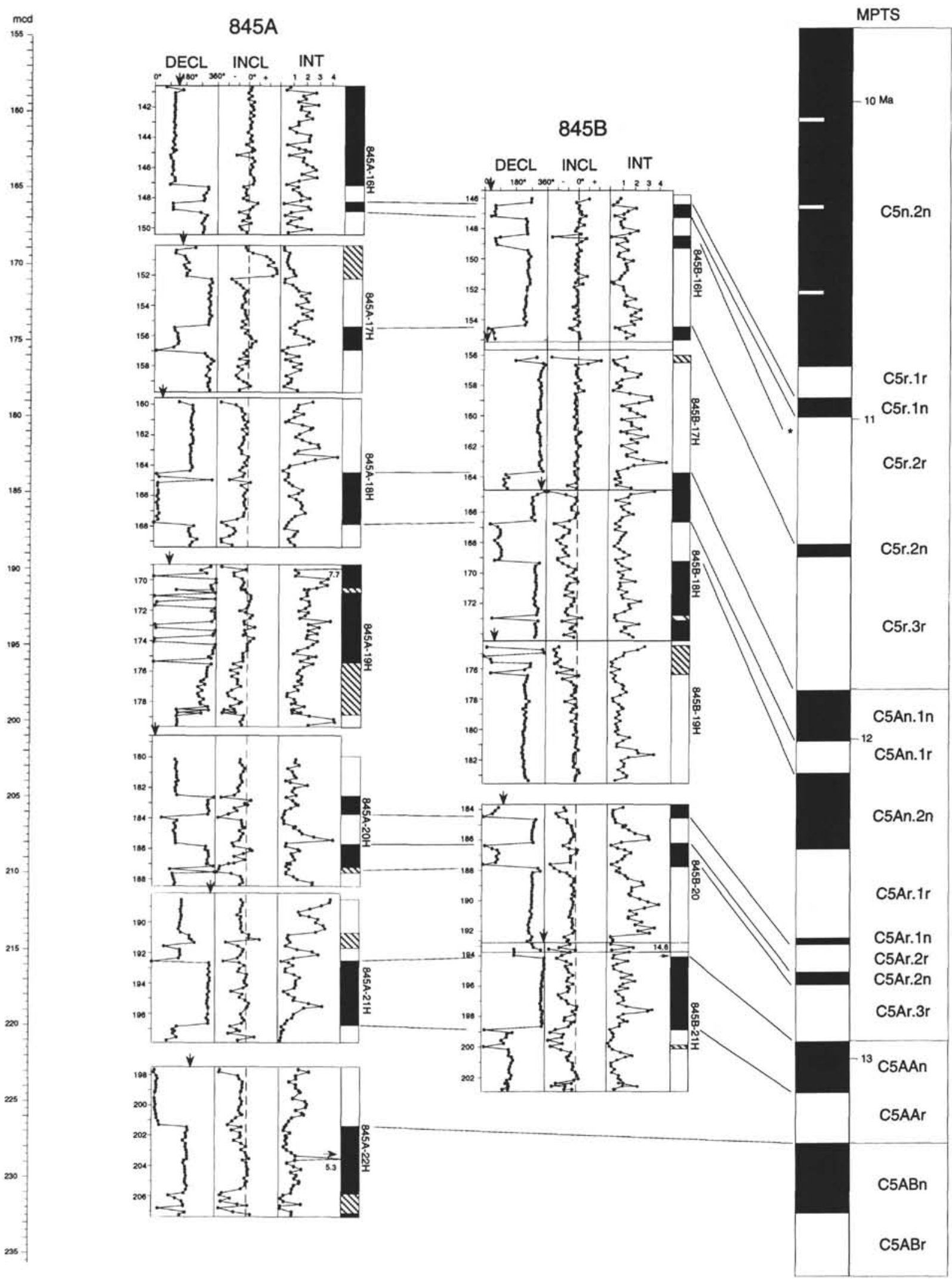

Figure 4. Magnetostratigraphy of the middle Miocene section of Site 845. Plotting conventions are as in Figure 1. Note that three high-intensity values (in Cores 138-845A-19H, 138-845A-22H, and 138-845B-21H), which plot off scale, are indicated with labeled horizontal arrows. Correspondence of a feature with a presumed cryptochron not included in the time scale of Cande and Kent (1992) is indicated with an asterisk. Paleomagnetic data are from discrete samples after 20-mT AF demagnetization. 


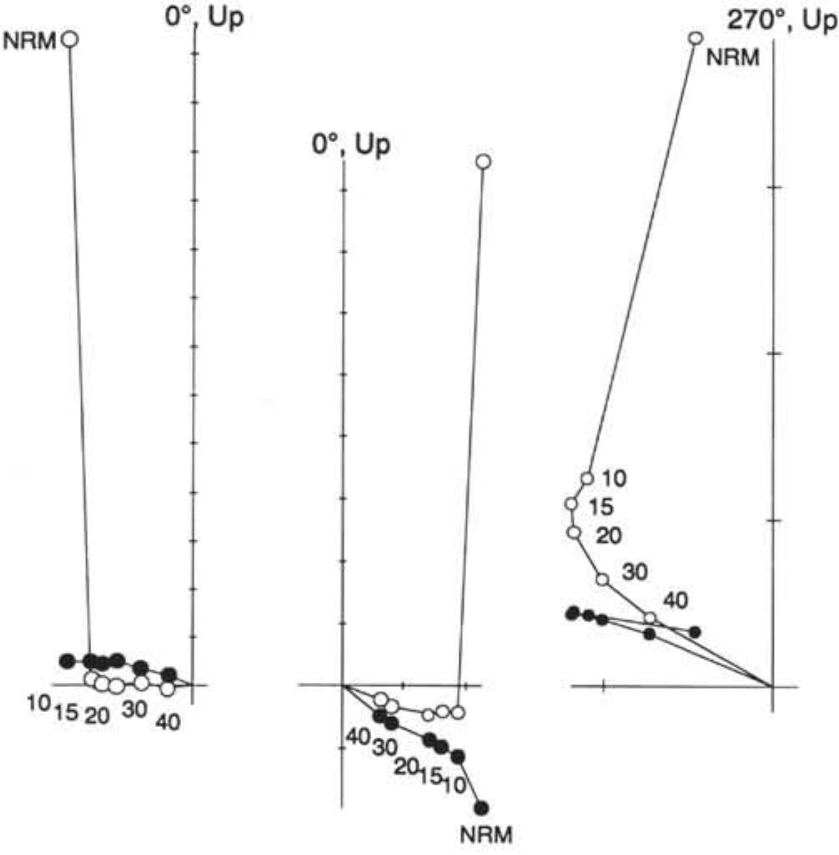

Figure 5. Representative demagnetization diagrams for samples from Hole $845 \mathrm{~A}$ showing that the strong vertical overprint associated with coring can contribute even after the $15-\mathrm{mT}$ demagnetization treatment applied during shipboard measurements. Left is Sample 138-845A-16H-6, 124-126 cm; middle is Sample 138-845A-16H-3, 124-126 cm; right is Sample 138-845A-18H$6,124-126 \mathrm{~cm}$. Open symbols denote projection on vertical plane, closed symbols on horizontal plane. Tick marks show $1 \mathrm{~mA} / \mathrm{m}$ graduations. Demagnetization levels applied (in $\mathrm{mT}$ ) are shown next to each point.

ous, that the photographic orientation is also incorrect, and that there is an anomalously large gap between this and the overlying core. This combination of events seems unlikely.

\section{Results: Pliocene Magnetostratigraphy}

The Pliocene magnetostratigraphy can be readily deduced from pass-through magnetometer measurements of Cores $138-845 \mathrm{~A}-6 \mathrm{H}$ to $-8 \mathrm{H}$ and $138-845 \mathrm{~B}-5 \mathrm{H}$ to $-8 \mathrm{H}$ (Fig. 2). (As mentioned, no magnetostratigraphic interpretation is possible above $50 \mathrm{mcd}$ in either hole, where remanent intensities are typically less than $1 \mathrm{~mA} / \mathrm{m}$.) Polarity can be assigned in each of these cores individually based on inclination changes, with the single exception of Core $138-845 \mathrm{~B}-8 \mathrm{H}$, where it can be assigned by transfer.

The correlation of the reversal sequence to the magnetic polarity time scale is facilitated by the many biostratigraphic datum levels available, allowing the 14 magnetozones found to be readily linked to the Pliocene age portion of the magnetic polarity time scale that encompasses Chrons $\mathrm{C} 2 \mathrm{An}$ to $\mathrm{C} 3 \mathrm{r}$ (Fig. 2). The results shown here essentially follow the shipboard interpretation; the single significant revision to the shipboard interpretation of the Pliocene section occurs in Core 138$845 \mathrm{~B}-6 \mathrm{H}$. In the initial shipboard interpretation, a reversal boundary at the base of this core was identified with the onset of $\mathrm{C} 3 \mathrm{n}$. $\ln$ (Cochiti). Because this does not occur at the same composite depth as the onset of $\mathrm{C} 3 \mathrm{n} .1 \mathrm{n}$ in Hole $845 \mathrm{~A}$, it seems more probable that this feature correlates with a thin anomalous zone just above the $\mathrm{C} 3 \mathrm{n}$. $1 \mathrm{n}$ onset in Hole 845A.

\section{Results: Upper Miocene Magnetostratigraphy}

The upper Miocene magnetostratigraphy has been similarly generated from pass-through magnetometer measurements (of Cores $138-845 \mathrm{~A}-9 \mathrm{H}$ to $-15 \mathrm{H}$ and $138-845 \mathrm{~B}-9 \mathrm{H}$ to $-15 \mathrm{H}$ ), as shown in Figure
3. The identification of the C5 long normal zone at the base of this section is straightforward, being well controlled by the series of nannofossil Zones CN5, CN6, and CN7. Further, the overall magnetostratigraphic framework is built on the identification of Chronozones $\mathrm{C} 4$ near $115 \mathrm{mcd}$ (in association with nannofossil Zone CN9a) and $\mathrm{C} 4 \mathrm{~A}$ near $135 \mathrm{mcd}$. More difficult is the interpretation of the various subchronozones, in particular, those that are only a few tens of centimeters thick. First, I consider the identification of the thicker, more distinct of these subchronozones; a detailed discussion of thinner features appears in the next section of the chapter that focuses on the magnetostratigraphic record of short subchrons not included in many polarity time scales.

During Chron C3, three normal subchrons lasted longer than 150 k.y.: C3An.1n, C3An.2n, and C3Bn. I made the obvious identification of the three thickest subchronozones in $\mathrm{C} 3$ with these intervals. A newly recognized feature of the GPTS is the presence of two short normal intervals within the lower reversed $\mathrm{C} 3 \mathrm{Br}(\mathrm{C} 3 \mathrm{Br} .1 \mathrm{n}$ and $\mathrm{C} 3 \mathrm{Br} .2 \mathrm{n}$ ); these can be readily associated with the thin normal polarity zones in Cores $138-845 \mathrm{~A}-11 \mathrm{H}$ and $-845 \mathrm{~B}-10 \mathrm{H}$. (Note that the interpretation of Core $138-845 \mathrm{~B}-10 \mathrm{H}$ given here corrects the original shipboard tabulation, which erroneously indicated $\mathrm{C} 4 \mathrm{n} .2 \mathrm{n}$ in this core). Advancing down the section, one can readily associate two normal zones (thickness of 2 and $8 \mathrm{~m}$ ) with the two longest normal subchrons of $\mathrm{C} 4(\mathrm{C} 4 \mathrm{n} .1 \mathrm{n}$ and $\mathrm{C} 4 \mathrm{n} .2 \mathrm{n})$. Below this level, two closely spaced, thin normal zones are found, one of which likely corresponds to $\mathrm{C} 4 \mathrm{r} .1 \mathrm{n}$. Another thin normal zone is seen about $7 \mathrm{~m}$ below this pair, but this magnetozone cannot be matched to any short feature in the GPTS. (See the more detailed discussion of this and other short polarity intervals included in the following section). Below this, the 7-m-thick normal zone can be readily associated with C4An and the two thinner (1-2 m) normal zones can be matched with C4Ar.1n and C4Ar.2n. Below, there remains in this upper Miocene section only the thick normal zone associated with $\mathrm{C} 5$, interrupted by one thin reversed zone that most likely corresponds to the single short reversed subchron within that long normal interval: C5n.1r.

\section{Results: Middle Miocene Magnetostratigraphy}

In general, the magnetization intensities within the middle Miocene section are smaller than those measured for the upper Miocene or lower Pliocene intervals considered previously. These relatively low intensities appear to compromise the reliability of the passthrough magnetometer measurements; thus, this section was completely remeasured using discrete samples taken at 20 -cm intervals. The magnetostratigraphic results (Fig. 4) are based entirely on these shore-based measurements.

For the most part, location of the various reversal boundaries and the determination of polarity sense is straightforward. However, two exceptions should be noted. The first significant problem is that the paleomagnetic data measured in the bottom half of Core 138-845A$19 \mathrm{H}$ do not match those measured in the top half of Core 138-845B$19 \mathrm{H}$, as the composite depth model suggests they should. In Core $138-845 \mathrm{~A}-19 \mathrm{H}$, the declinations rotate gradually through $90^{\circ}$ and abruptly shift an additional $100^{\circ}$ or more at $199 \mathrm{mcd}$, with some degree of oscillation between. The correlative interval in Core 138$845 \mathrm{~B}-19 \mathrm{H}$ shows no matching behavior. Although paleomagnetic directions near the top of Core 138-845B-19H are erratic (this is not particularly unexpected because core tops are the most prone to contamination or physical disturbance), the core generally shows near-zero inclinations and a consistent declination down the core. Because the susceptibility, density, and color logs all show clear correlations between these two cores, the inconsistency of the paleomagnetic data cannot be explained by an error in the composite depth model. The simplest interpretation is that the erratic magnetization directions seen in Core $138-845 \mathrm{~A}-19 \mathrm{H}$ are largely spurious and that the consistent directions observed in Core $138-845 \mathrm{~B}-19 \mathrm{H}$ provide the better record of the paleomagnetic field. 
A second problem occurs with the determination of polarity sense in the basal APC core of the section, Core 138-845A-22H. Polarity assignment by transfer from Core 138-845B-21H (based on overlapping stratigraphy) matches that derived from photographic orientation. This polarity interpretation suggests that overprint directions should be opposite to the primary component in the upper reversed interval. As mentioned in the discussion of polarity assignment, this was not observed. The declination of the overprint in this core is opposite the primary declination in samples from the lower (presumably normal) half of the core. Here, I am forced to discount the overprint direction.

Other than this one problematic example, the assignment of polarity sense is clear. The polarity choice in Core $138-845 \mathrm{~A}-16 \mathrm{H}$ is obvious both from the presence of $\mathrm{C} 5 \mathrm{n} .2 \mathrm{n}$ and from the distinct inclination changes near the base of the core. This choice of polarity sense transfers immediately to Cores $138-845 \mathrm{~B}-16 \mathrm{H}, 138-845 \mathrm{~A}-17 \mathrm{H}, 138-845 \mathrm{~B}-$ $17 \mathrm{H}, 138-845 \mathrm{~A}-18 \mathrm{H}$, and $138-845 \mathrm{~B}-18 \mathrm{H}$ by overlapping stratigraphy. Even discounting all data from the problematic Core $138-845 \mathrm{~A}-19 \mathrm{H}$, one can connect the six cores $(138-845 \mathrm{~B}-19 \mathrm{H}, 138-845 \mathrm{~A}-20 \mathrm{H}, 138-$ $845 \mathrm{~B}-20 \mathrm{H}, 138-845 \mathrm{~A}-21 \mathrm{H}, 138-845 \mathrm{~B}-21 \mathrm{H}$, and $138-845 \mathrm{~A}-22 \mathrm{H})$ by stratigraphic overlapping. Although inclination changes are nowhere entirely clear within this package of six cores, all six photographic orientations taken are consistent with the choice of polarity sense shown. The alternative choice of polarity sense in this package of cores could be correct only if all six of the photographic orientations were $180^{\circ}$ in error. Although occasionally $180^{\circ}$ errors in photographic orientation did occur during the cruise, these were exceptions and it is most unlikely that six such errors would occur consistently in this package of six linked cores.

The identification of the magnetozones begins with the thick normal associated with $\mathrm{C} 5 \mathrm{n} .2 \mathrm{n}$, which appears in Core 138-845A$16 \mathrm{H}$ at the top of the section. Directly below the base of this normal zone are two thin normal subchrons, only one of which can be matched to a comparable feature of the GPTS (C5r.1n). The thin normal zone about $7 \mathrm{~m}$ below this pair can be reasonably associated with $\mathrm{C} 5 \mathrm{r} .2 \mathrm{n}$, as can the thicker ( 3 and $6-\mathrm{m}$ wide) normal zones below be associated with C5An.1n and C5An.2n. Farther down the section are two thin normal zones ( 1 - to $2-\mathrm{m}$ wide) associated with C5Ar. $\mathrm{n}$ and C5Ar.2n and two thick normal zones ( 4-m wide) associated with C5AAn and C5ABn. This interpretation thus implies that sedimentation at Site 845 was largely continuous since about $13.5 \mathrm{Ma}$.

The magnetostratigraphic interpretation of this important middle Miocene section also conforms with the albeit loose biostratigraphic constraints available for this interval. For example, the identification of the last occurrence of Cyclicargolithus floridanus in the middle of Core 138-845A-22H (Mayer, Pisias, Janecek, et al., 1992) corresponds well with the expectation that this event occurred near C5AAr time (Backman et al., 1990). It should be stressed, however, that the interpretation of the reversal sequence in this section is based largely on the relative spacing of the various magnetozones. Biostratigraphy provides broad age control, but detailed ages for many of the biostratigraphic events contained within these cores have not been well docu- mented in a low-latitude environment. Indeed, the magnetostratigraphic age control available at this site offers one of the best sections for generating such middle Miocene age calibrations.

\section{MIOCENE CRYPTOCHRONS}

\section{General Considerations}

Geomagnetic events shorter than about $30,000 \mathrm{yr}$, be they short episodes of full polarity, magnetic excursions, or merely intensity fluctuations, are not well resolved by the marine magnetic record and so are only haphazardly included in geomagnetic polarity time scales. Although the record of such limited duration phenomena is relatively well documented for the Pliocene-Pleistocene, knowledge of short intervals in the Miocene is much scarcer. Borrowing the term from Cande and Kent's (1992) recent study of the magnetic polarity time scale, I will refer to such short geomagnetic phenomena as crypto- chrons. (To be formal, I will term the corresponding magnetozones cryptochronozones.)

The pass-through magnetometer records obtained during Leg 138 identified seven Miocene age cryptochronozones. These features correlate between sites on both eastern and western transects, demonstrating that they reflect more than local sedimentological disturbance or coring artifacts, and are not included in the polarity time scale of Berggren et al. (1985), which was adopted for shipboard work. Three of the seven events can reasonably be elevated from cryptochron status according to $\mathrm{CK} 92$, which includes these as short, full-polarity intervals. The two youngest of these zones correlate with polarity intervals $\mathrm{C} 3 \mathrm{Br}$. In and $\mathrm{C} 3 \mathrm{Br} .2 \mathrm{n}$; the short reverse polarity interval near the end of C5 correlates with C5n.1r. Another of the short events recorded in these sediments most likely correlates with the CK92 cryptochron $\mathrm{C} 4 \mathrm{r} .2 \mathrm{r}-1$; the correlative events corresponding to the remaining three zones are previously unrecognized and are here given names following the CK92 cryptochron terminology (Fig. 6).

\section{Method}

To determine whether these short zones reflect brief intervals of lowered geomagnetic intensity or are the result of true full-polarity intervals, I have analyzed a series of discrete samples spanning each of the seven zones. The discrete sample results are much simpler to interpret than the pass-through measurements, which can indicate spurious reversals in $\mathrm{X}$ and $\mathrm{Y}$ components over a low-intensity interval (Schneider and Kent, 1990). Moreover, the discrete samples allow one to determine relative paleointensities using anhysteretic remanent magnetization (ARM) as a normalization for variations in the amount of magnetic carrier (King et al., 1983).

I sampled each zone twice, choosing one western and one eastern transect site, to demonstrate that the features under study are discernible over a reasonably large geographical extent. The sample spacing is $10 \mathrm{~cm}$. All samples received progressive alternating field (AF) demagnetization. To save time, most samples were not completely demagnetized; however, demagnetization was taken to levels adequate to remove the obvious vertical overprint that proved pervasive during this leg. The characteristic magnetization is shown by the component remaining after this low-coercivity overprint was removed. I determined the direction of this high-coercivity component using principal component analysis (Kirschvink, 1980), forcing the vector being fit to be anchored to the origin. I also estimated relative intensities using the ratio of intensity of natural remanent magnetiza-

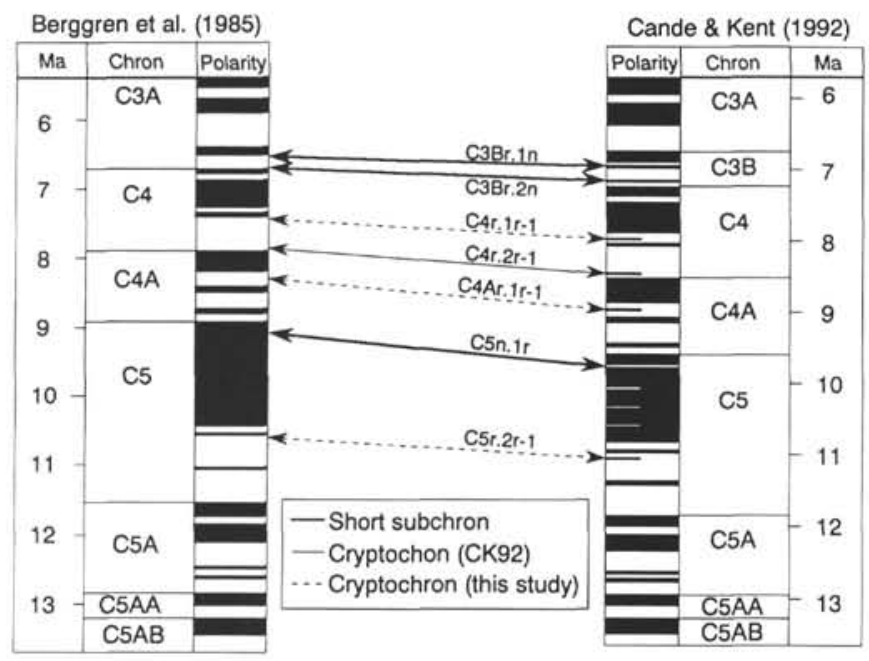

Figure 6. Short events documented in this study. Left panel shows age of the seven events not included in the shipboard standard time scale (from Berggren et al., 1985). Right panel shows the age of these events relative to CK92. 
tion (NRM), after $20 \mathrm{mT}$ treatment, to the intensity of magnetization of ARM (from $100 \mathrm{mT}$ alternating and $0.1 \mathrm{mT}$ constant fields), after $\mathrm{AF}$ demagnetization to the same level.

\section{Results}

The two youngest of these short intervals clearly correlate with $\mathrm{C} 3 \mathrm{Br}$. $1 \mathrm{n}$ and $\mathrm{C} 3 \mathrm{Br} .2 \mathrm{n}$ of $\mathrm{CK} 92$. $\mathrm{C} 3 \mathrm{Br} .1 \mathrm{n}$ is a short normal polarity interval just prior to the longer $\mathrm{C} 3 \mathrm{Bn} ; \mathrm{C} 3 \mathrm{Br} .2 \mathrm{n}$ is a short normal polarity interval just after $\mathrm{C} 4 \mathrm{n}$. In. In the cores examined (Fig. 7), the relative paleointensity appears to recover in intensity from the transitional lows bounding both these short normal polarity intervals. Although this is not well displayed for $\mathrm{C} 3 \mathrm{Br}$. In at the western transect Core 138-854B$3 \mathrm{H}$, it is well shown in eastern transect Core 138-845B-10H. The difference in the two records is probably a function of the limited resolution of the sampling: some transitional intensity lows may easily have been missed in the $10-\mathrm{cm}$ space between adjacent samples.

The next oldest pair of zones in question, cryptochronozone C4r.2r-1 and a previously unnamed zone, both most likely reflect periods of anomalously low geomagnetic intensity (Fig. 8). Each of the four cores examined show relative paleointensity lows within these intervals and none shows much suggestion of any recovery of intensity. Although these zones are quite thin, their thickness in the Site 845 cores (about $25 \mathrm{~cm}$ and $75 \mathrm{~cm}$ ) should be adequate to discern a recovery of intensity had it occurred. Following the nomenclature of CK92 suggests this cryptochron be named C4r.1r-1.

The next oldest pair of zones (Fig. 9), reflecting a previously unnamed interval and C5n. $1 \mathrm{r}$, probably represent an intensity low and a short, full-polarity zone, respectively. Although C5n.1r is not well resolved at western transect Core $138-848-10 \mathrm{H}$, it is clearly displayed at eastern transect Core 138-845B-14H: there, it is about $60 \mathrm{~cm}$ thick and shows a clear recovery in intensity within this reversed polarity zone. The unnamed zone within C4Ar.2r is reasonably well resolved (particularly in western transect Core $138-854 \mathrm{C}-6 \mathrm{H}$, where it is about $50 \mathrm{~cm}$ thick); however, discrete samples of this zone show low intensities and scattered directions that do not suggest this was caused by a full-polarity interval. The terminology of CK92 suggest this cryptochron be assigned the name C4Ar.1r-1.

Documentation of the oldest of the suspect zones comes from only one site: it is found in Core $138-845 \mathrm{~B}-16 \mathrm{H}$. The corresponding portion of Hole $845 \mathrm{~A}$ falls squarely in the gap between Cores $138-845 \mathrm{~A}-16 \mathrm{H}$ and $138-845 \mathrm{~A}-17 \mathrm{H}$. This unnamed zone appears in the upper part of C5r, just below C5r.1n and would seem to reflect a short interval of full normal polarity: paleomagnetic directions show clear normal polarity directions and the relative paleointensity indicates a distinct recovery within the zone (Fig. 10). Indeed, this normal polarity zone gives a record that is nearly as clear as the slightly thicker C5r. In zone found higher in the core. But because the paleomagnetic record of this short interval is available only from one core, it may be premature to confirm this as a full-polarity subchron. Thus I have termed it here C5r.2r-1, reflecting, for the time being, cryptochron status.

These results allow the age and duration of these intervals to be estimated. Although durations can, in principle, be determined simply from thickness and sedimentation rate, in practice, it is challenging to make firm assessments because it is difficult to define objectively the beginning and ending points of some of these features. The fullpolarity zones can, however, be reasonably defined by the relative intensity lows that mark the polarity transitions bounding these short

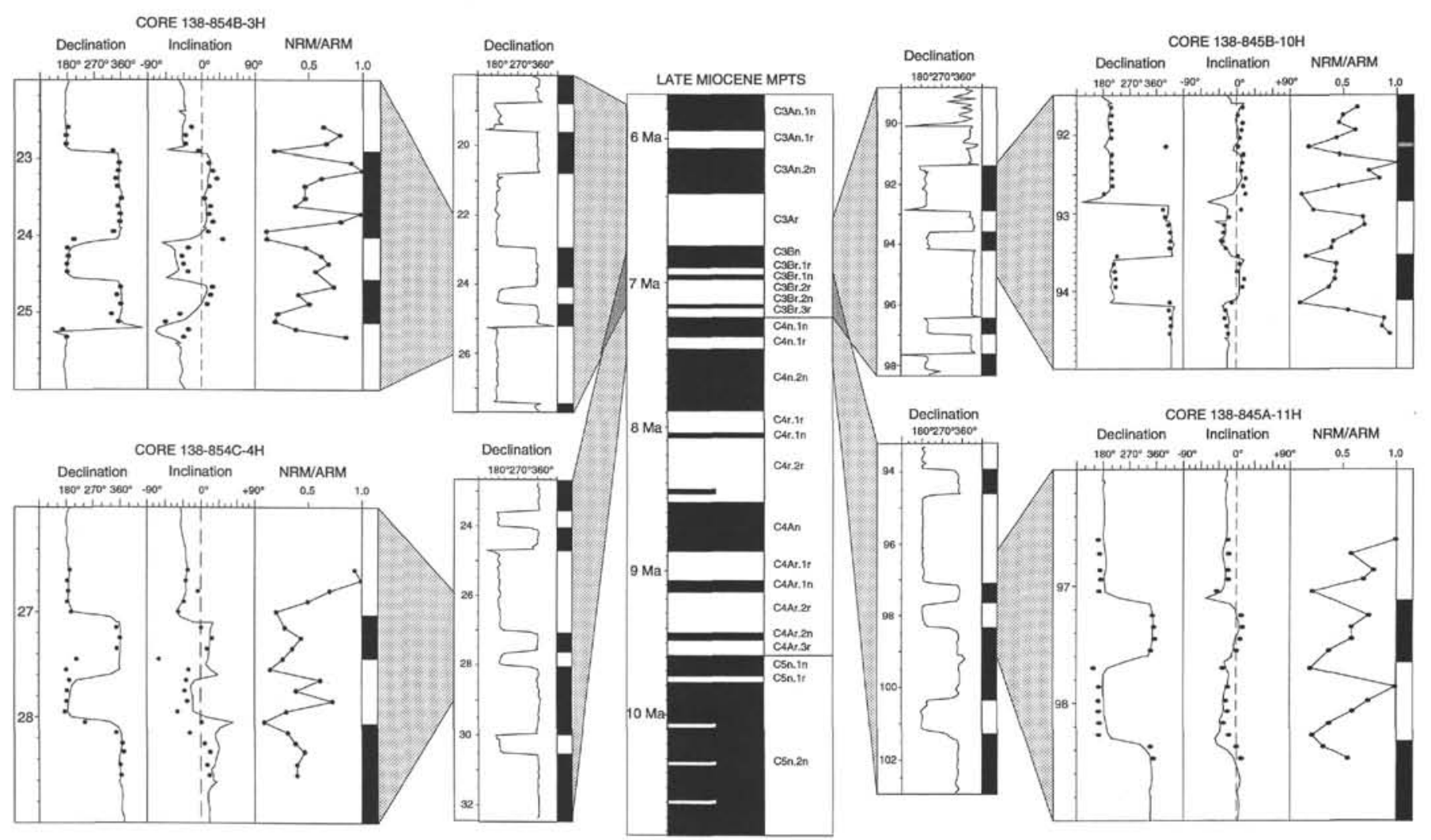

Figure 7. Magnetic polarity stratigraphy of two short events ( $\mathrm{C} 3 \mathrm{Br}$.1n and $\mathrm{C} 3 \mathrm{Br} .2 \mathrm{n}$ ) documented in western (Cores 138-854B-3H and 138-854C-4H) and eastern (Cores 138-845B-10H and 138-845A-11H) transect sites. Solid lines indicate directions determined from shipboard pass-through magnetometer measurements after 15-mT demagnetization. Points show directions of high-coercivity component revealed by progressive AF demagnetization of discrete samples. Relative intensity is given by the ratio of NRM after 20-mT demagnetization to ARM (acquired in 100-mT AF and 0.1-mT constant field) after 20-mT demagnetization. Intensity ratio results are scaled to 1 for each core. All depths are shown in nominal meters below seafloor. The late Miocene magnetic polarity time scale shown (CK92) indicates cryptochrons using half-length bars. 


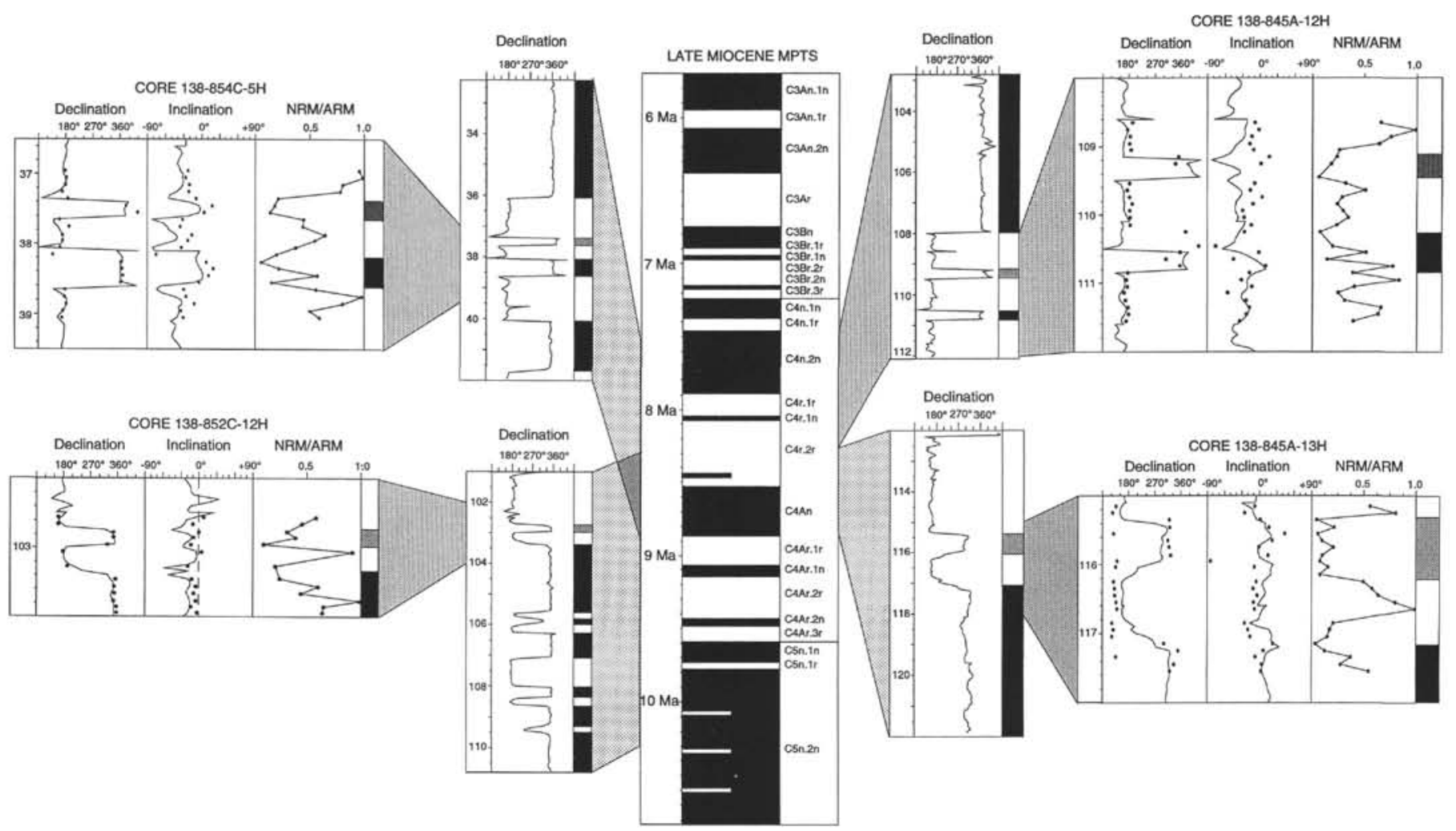

Figure 8. Magnetic polarity stratigraphy of two short events (cryptochron C4r.2r-1 and an unnamed event) documented in western (Cores $138-854 \mathrm{C}-5 \mathrm{H}$ and $138-852 \mathrm{C}-12 \mathrm{H}$ ) and eastern (Core 138-845A-12H and 138-845 A-13H) transect sites. Plotting conventions are as in Figure 7 . Shading indicates zones that most likely reflect periods of diminished geomagnetic intensity.

Table 2. Estimated durations of short subchrons.

\begin{tabular}{cccccc}
\hline Zone & \multicolumn{1}{c}{ Core } & $\begin{array}{c}\text { Interval } \\
(\mathrm{mbs})\end{array}$ & $\begin{array}{c}\text { Thickness } \\
(\mathrm{cm})\end{array}$ & $\begin{array}{c}\text { Sedimentation rate } \\
(\mathrm{cm} / \mathrm{k} . \mathrm{y} .)\end{array}$ & $\begin{array}{c}\text { Duration } \\
(\mathrm{k} . \mathrm{y} .)\end{array}$ \\
\hline C3Br.1n & $845 \mathrm{~B}-10 \mathrm{H}$ & $93.55-94.15$ & 60 & 1.4 & $43(35)$ \\
& $854 \mathrm{~B}-3 \mathrm{H}$ & $24.47-25.07$ & 60 & 1.3 & $46(35)$ \\
$\mathrm{C} 3 \mathrm{Br} .2 \mathrm{n}$ & $854 \mathrm{C}-4 \mathrm{H}$ & $27.00-27.55$ & 55 & 1.3 & $42(34)$ \\
& $845 \mathrm{~A}-1 \mathrm{IH}$ & $97.04-97.70$ & 66 & 1.4 & $47(34)$ \\
$\mathrm{C} 5 \mathrm{n} . \mathrm{Ir}$ & $848 \mathrm{~B}-10 \mathrm{H}$ & $84.65-84.85$ & 20 & $0.3^{*}$ & $66(47)$ \\
& $845 \mathrm{~B}-14 \mathrm{H}$ & $134.80-135.57$ & 77 & $1.4^{* *}$ & $55(47)$ \\
C5r.2r-1 & $845 \mathrm{~B}-16 \mathrm{H}$ & $148.56-149.05$ & 49 & 1.9 & $26(-)$
\end{tabular}

Note: Sedimentation rates are calculated on the basis of bracketing reversals within the core and their assigned ages according to the time scale of Cande and Kent (1992). Because no lower reversals were found at this site, the sedimentation rate marked * has been determined using the thickness of $\mathrm{C} 5 \mathrm{n}$. In in this core. Because the bracketing reversals were not found within this core, the value marked ** was determined using composite depths. For comparison with these results, the corresponding duration estimates (taken directly from the time scale of Cande and Kent. 1992) are shown in parentheses.

Table 3. Estimated ages of newly named cryptochrons.

\begin{tabular}{|c|c|c|c|}
\hline Zone & Core & $\begin{array}{l}\text { Center } \\
\text { (mbsf) }\end{array}$ & $\begin{array}{l}\text { Age } \\
\text { (Ma) }\end{array}$ \\
\hline C4r.1r-1 & $\begin{array}{l}845 \mathrm{~A}- \\
12 \mathrm{H}\end{array}$ & 109.20 & 7.960 \\
\hline C4Ar.1r-1 & $\begin{array}{c}854 \mathrm{C}-5 \mathrm{H} \\
845 \mathrm{~B}- \\
13 \mathrm{H}\end{array}$ & $\begin{array}{r}37.50 \\
123.70\end{array}$ & $\begin{array}{l}8.004 \\
8.968\end{array}$ \\
\hline C5r.2r-1 & $\begin{array}{c}854 \mathrm{C}-6 \mathrm{H} \\
845 \mathrm{~B}- \\
16 \mathrm{H}\end{array}$ & $\begin{array}{r}46.70 \\
148.80\end{array}$ & $\begin{array}{r}8.968 \\
11.073\end{array}$ \\
\hline
\end{tabular}

Note: Ages were estimated using the depths of bracketing reversals and their ages according to the time scale of Cande and Kent (1992). subchrons. The results for four zones (Table 2) show that the duration of these events ranges from about $26 \mathrm{ky}$ to $55 \mathrm{ky}$. Estimated ages for the three cryptochrons not included in CK92 are given in Table 3.

\section{Implications}

For the most part, the magnetostratigraphic analysis supports the polarity history of these short events as given in CK92 (Fig. 6). Three events, C3Br.1n, C.Br.2n, and C5n.1r, are confirmed as full-polarity intervals by relative paleointensity records that show recovery of intensity during these brief subchrons. The existence of the CK92 cryptochron $\mathrm{C} 4 \mathrm{r} \cdot 2 \mathrm{r}-1$ is also supported by the magnetostratigraphic data that indicate that this is an interval of anomalously low field intensity.

There are, however, no indications of the three cryptochrons within C5n (C5n.2n-1, C5n.2n-2, and C 5n.2n-3). This could be explained by the potential bias against recovery of short reverse-polarity zones, which might tend to be masked by residual normal overprints. However, it may well be that the magnetostratigraphy of Site 845 does not show any obvious features corresponding to three "tiny wiggles" of the seafloor-spreading magnetic record (Blakely, 1974) because these did not result from full polarity reversals or distinct intervals of lowered geomagnetic intensity. Rather, the seafloor signal may have been generated by intensity oscillations that were large in an absolute sense, but small relative to the mean value of intensity during the $\mathrm{C} 5 \mathrm{n}$ interval.

There also remains some discrepancy in the duration of the short full-polarity subchrons observed. The magnetostratigraphic estimates of their duration (Table 2) appear to be consistently larger than the corresponding intervals specified in CK92. Further, it appears that three more subtle events can be documented here as real geomagnetic features (the oldest one may, in fact, be a 26-k.y.-long full-polarity subchron), but do not appear even as cryptochrons in CK92.

The stratigraphic utility of these subtle geomagnetic features should not be underestimated. An excellent example of their usefulness is 


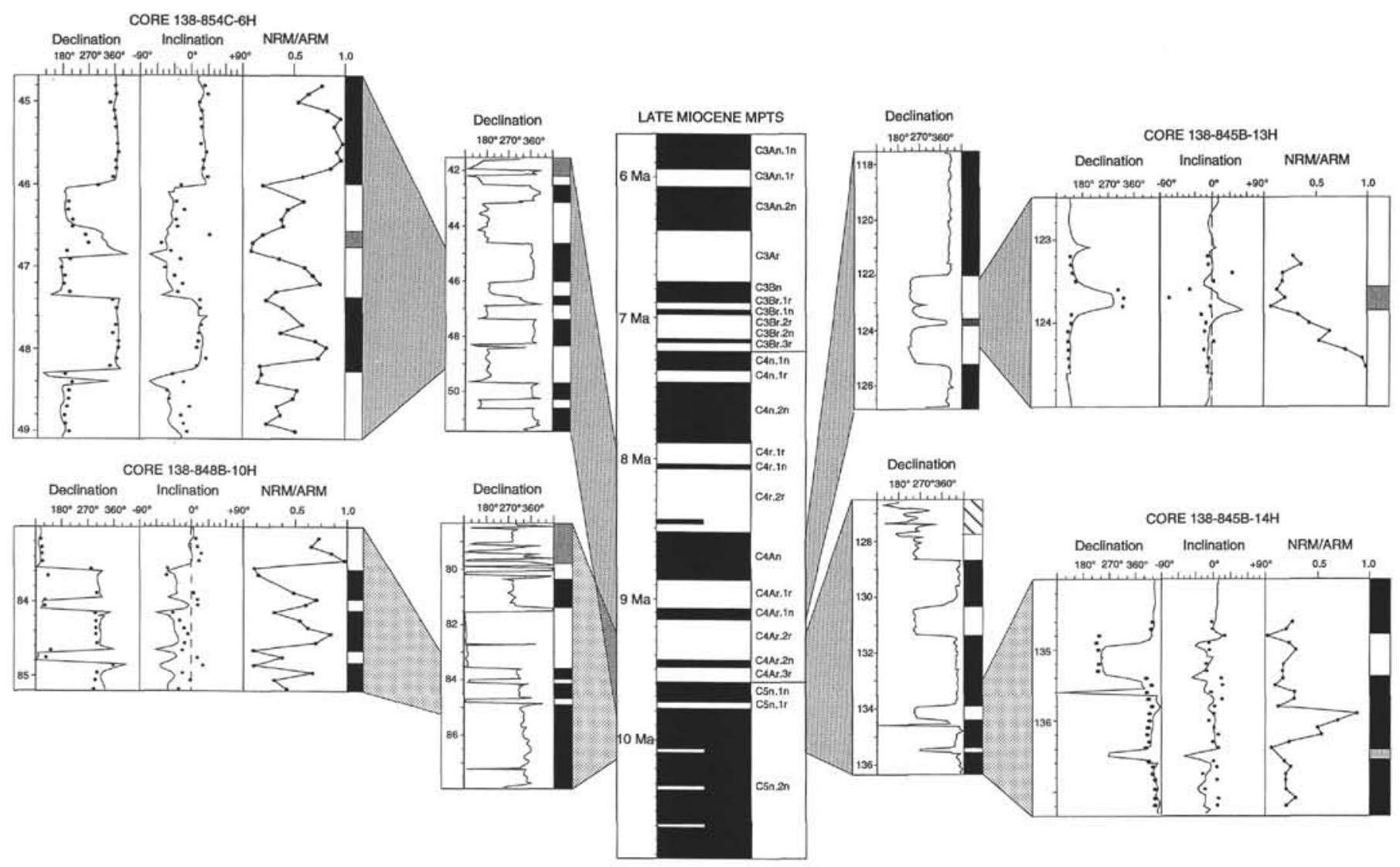

Figure 9. Magnetic polarity stratigraphy of two short events (an unnamed event and C5n.1r) documented in western (Cores 138-854C-6H and 138-848B-10H) and eastern (Core 138-845B-13H and 138-845B-14H) transect sites. Plotting conventions are as in Figure 7. Hachures in the polarity column of Core 138-845B-14H indicate that no interpretation was made.

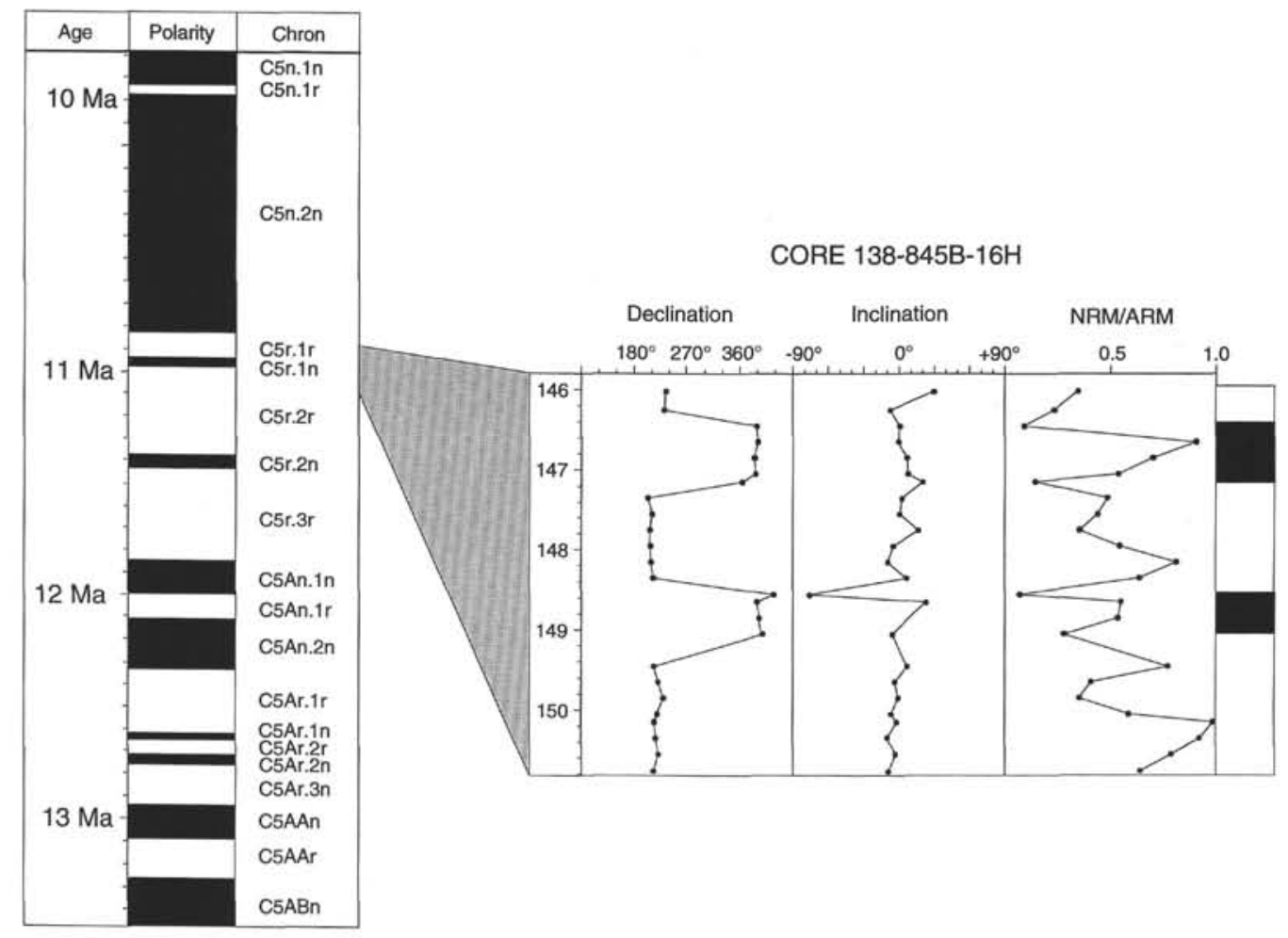

Figure 10. Magnetic polarity stratigraphy of an unnamed short event documented only in one eastern transect core (Core $138-845 \mathrm{~B}-16 \mathrm{H}$ ) from discrete sample results. Declination and inclination values shown are from discrete samples demagnetized at $20 \mathrm{mT}$; intensity normalization is as described for Figure 7. 


\section{Hole $844 \mathrm{~A}$}

Hole 844 B Hole 844 C Hole 844 D
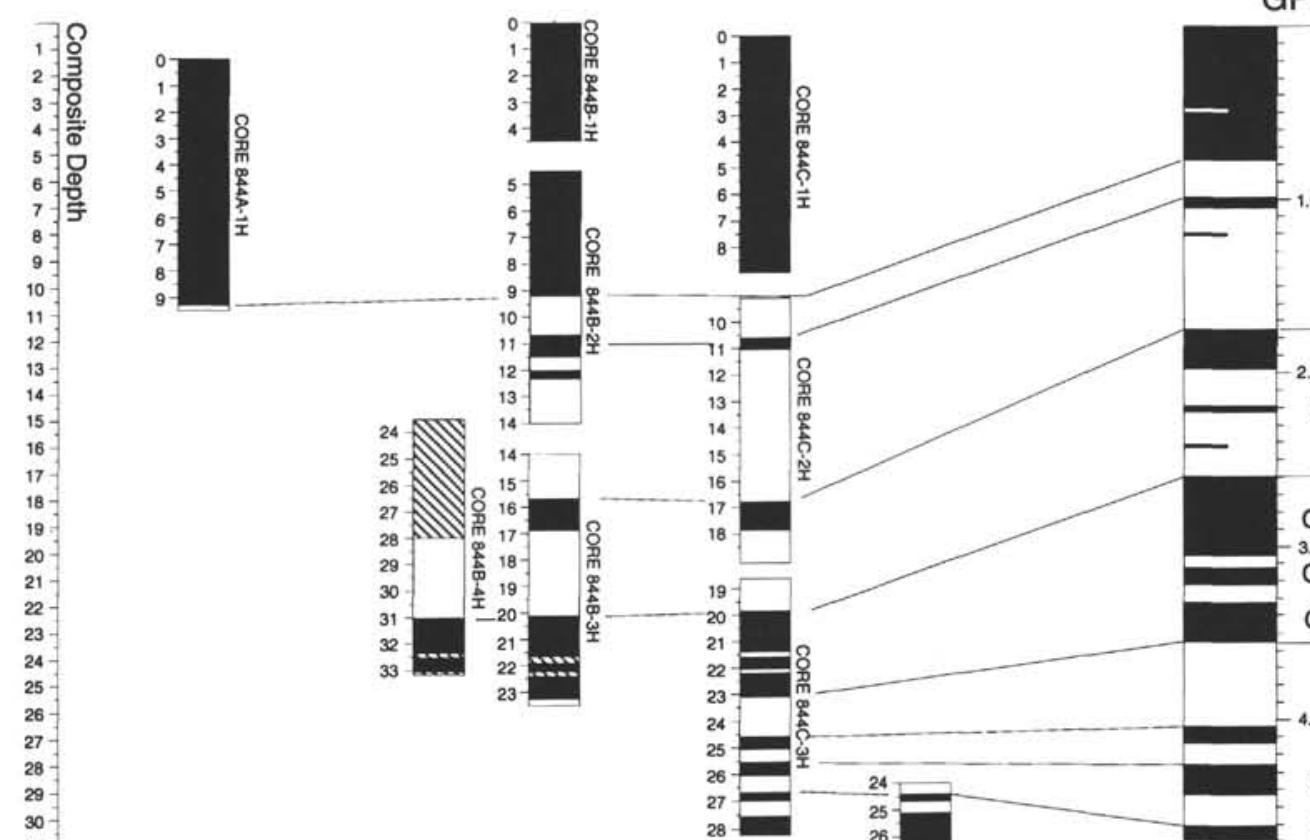

$-{ }^{4.0} \mathrm{C} 3 \mathrm{n} .1 \mathrm{n}$
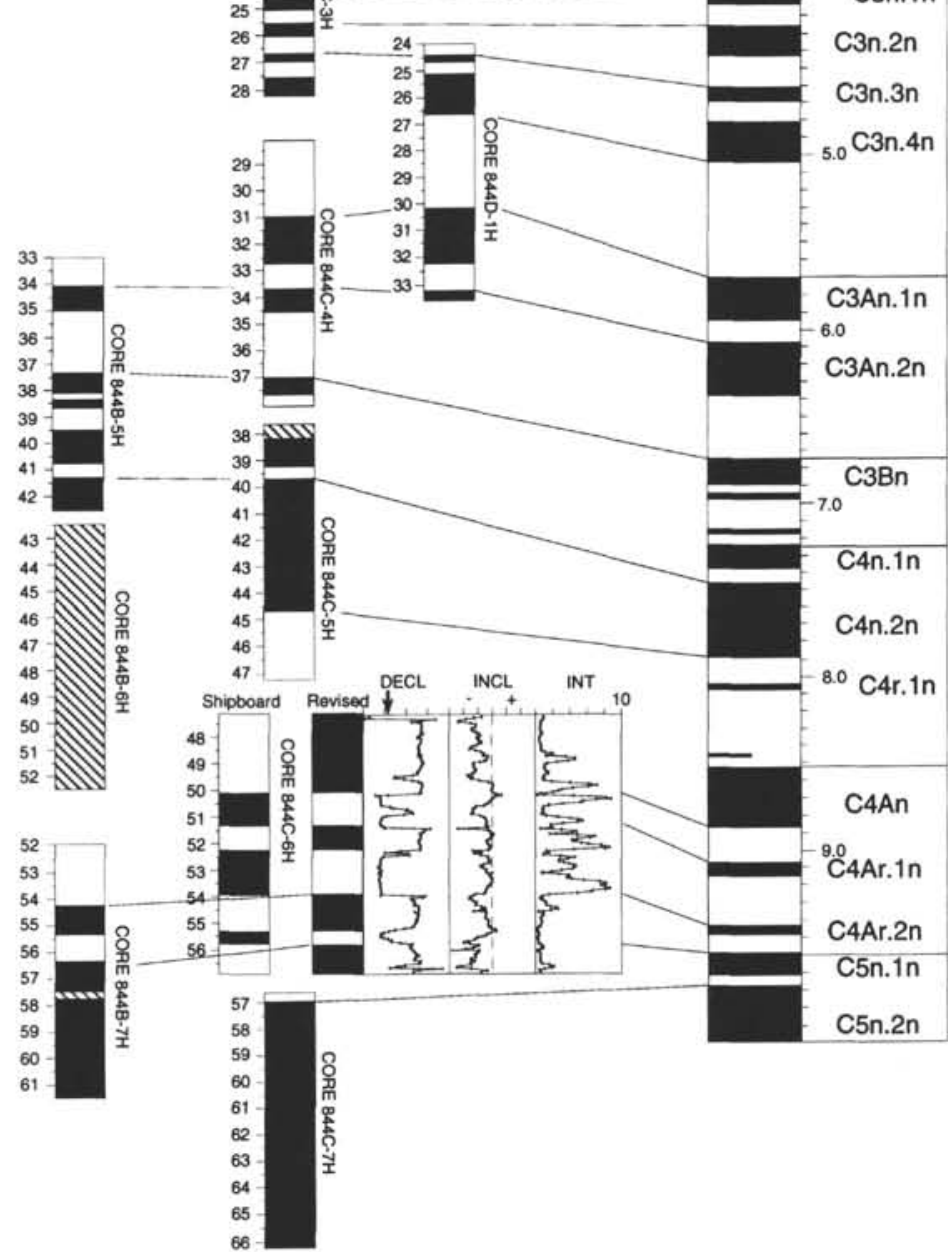

Figure 11. Revision of the shipboard polarity stratigraphy for Site 844 using the alternate polarity sense for Core $138-844 \mathrm{C}-6 \mathrm{H}$. Paleomagnetic data for this core are shown with declinations, relative to the double fiducial line on the core liner, plotted on $0^{\circ}$ to $360^{\circ}$ scale; inclinations from $-90^{\circ}$ to $+90^{\circ}$; intensity from 0 to $10 \mathrm{~mA} / \mathrm{m}$. Arrow on declination panel shows predicted declination of geographic north based on the photographic orientation of this core. The reinterpretation of polarity sense ignores this photographic orientation and is more consistent with the finding of a cryptochronozone that correlates with the newly identified cryptochron C4Ar.1r-1. Other core panels show only polarity interpretation (black = normal polarity; white = reversed polarity; hachured $=$ no assignment). Depth scale attached to each panel indicates nominal meters below seafloor. Scale at left indicates meters composite depth. 
available from the paleomagnetic study of Site 844. Shipboard interpretation of the magnetostratigraphy of Site 844 (Mayer, Pisias, Janecek, et al., 1992) implies that no short anomalous zone occurs within what had been identified as C4Ar.1r. However, it would appear that an anomalous zone does occur within what had been identified as C4An. This discrepancy suggests that the shipboard interpretation of this interval should be reconsidered. Indeed, reliance on photographic orientation probably led to an error when determining polarity sense in this one core (Core 138-844C-6H), which resulted in an incorrect shipboard interpretation of the magnetostratigraphic sequence. Taking the opposite polarity sense for Core $138-844 \mathrm{C}-6 \mathrm{H}$ reconciles the presence of a short anomalous interval with what is found at other sites; it further improves the correlation between adjacent holes (which otherwise show significant disagreement when adjusted to composite depth); finally, it suggests a more satisfying correlation with the geomagnetic polarity time scale (Fig. 11 and Table 4).

Because detailed demagnetization data are available for intervals surrounding these short events, I have also calculated paleolatitudes from the inclination of the full-polarity samples measured in some of the cores (Table 5). In general, the averaged inclination results show that reverse polarity directions tend to be about $10^{\circ}$ steeper than normal polarity, suggesting that the upward overprint is incompletely removed by demagnetization. Nevertheless, the paleolatitude estimates determined from combined normal and reverse polarity sediments do appear in reasonably good agreement with paleopositions calculated using the assumption of fixed hot spots.

\section{CONCLUSIONS}

Although the shipboard determination of paleomagnetic reversal stratigraphy using pass-through magnetometer data proved immensely successful, follow-up study of discrete samples remains an important adjunct to these initial measurements. This study indicates that discrete sample results generate a reversal stratigraphy for a critical middle Miocene interval (Site 845), where generally low intensities made a reliable magnetostratigraphic record more difficult to obtain from the pass-through magnetometer. Paleomagnetic analysis of discrete samples also allow one to apply an ARM for use as a relative paleointensity normalization. With this normalization, discrete samples reveal in detail the nature of various short intervals initially identified only crudely by the shipboard pass-through measurements.

The dual aspects of this study, refining the Miocene magnetostratigraphy of key sites and documenting short events, are not isolated objectives. The many short events recorded with paleomagnetic data from Leg 138 could not be reasonably documented without the integrated biostratigraphic and magnetostratigraphic framework available for the various cores in which these many events are recorded. Conversely, better documentation of short geomagnetic events during the Miocene suggests their stratigraphic utility: these features impose an added character to the magnetostratigraphic record that allows specific magnetozones to be identified readily. Thus, the recognition of short events in these Leg 138 cores helps to confirm (or to modify, in the case of Site 844) the overall magnetostratigraphic determinations and so serves to provide more reliable age models for the sediments obtained during the cruise.

\section{ACKNOWLEDGMENTS}

Discussions with Dennis Kent, Mickey van Fossen, and Jeff Gee helped to improve this study. I appreciate also the efforts of Jim Channell for reviewing the manuscript, Gilberto Mello for help in the laboratory, as well as various members of the Shipboard Scientific Party and the Gulf Coast Repository for aid during post-cruise sampling. This work was supported by a post-doctoral scholarship from the Woods Hole Oceanographic Institution's Education Office and by a post-cruise grant from USAAC. This is Woods Hole Oceanographic Institution Contribution No. 8380.
Table 4. Revised reversal boundary depths for Site 844 .

\begin{tabular}{|c|c|c|c|c|}
\hline $\begin{array}{l}\text { Core, section, } \\
\text { interval }(\mathrm{cm})\end{array}$ & $\begin{array}{l}\text { Depth } \\
\text { (mbsf) }\end{array}$ & $\begin{array}{l}\text { Depth } \\
\text { (mcd) }\end{array}$ & Interpretation & $\begin{array}{l}\text { Age } \\
(\mathrm{Ma})\end{array}$ \\
\hline $\begin{array}{l}138-844 \mathrm{~A}- \\
1 \mathrm{H}-7.15\end{array}$ & 9.15 & 10.55 & $\mathrm{Cln} / \mathrm{Clr} .1 \mathrm{r}$ & 0.780 \\
\hline $\begin{array}{l}138-844 \mathrm{~B}- \\
2 \mathrm{H}-4,20 \\
2 \mathrm{H}-5,20 \\
2 \mathrm{H}-5,100 \\
2 \mathrm{H}-6,30 \\
3 \mathrm{H}-2,20 \\
3 \mathrm{H}-2,135 \\
3 \mathrm{H}-5,15 \\
3 \mathrm{H}-7,25 \\
4 \mathrm{H}-5,140 \\
4 \mathrm{H}-7,0 \\
4 \mathrm{H}-7,55 \\
4 \mathrm{H}-7,55 \\
5 \mathrm{H}-1,105 \\
5 \mathrm{H}-2,50 \\
5 \mathrm{H}-3,135 \\
5 \mathrm{H}-4,65 \\
5 \mathrm{H}-4,90 \\
5 \mathrm{H}-4,120 \\
5 \mathrm{H}-5,50 \\
5 \mathrm{H}-6,25 \\
5 \mathrm{H}-6,80 \\
7 \mathrm{H}-2,75 \\
7 \mathrm{H}-3,30 \\
7 \mathrm{H}-3,130\end{array}$ & $\begin{array}{l}9.20 \\
10.70 \\
11.50 \\
12.30 \\
15.70 \\
16.85 \\
20.15 \\
23.25 \\
30.90 \\
32.40 \\
32.50 \\
33.05 \\
34.05 \\
35.00 \\
37.35 \\
38.15 \\
38.40 \\
38.70 \\
39.50 \\
40.75 \\
41.30 \\
54.25 \\
55.30 \\
56.30\end{array}$ & $\begin{array}{l}10.33 \\
11.83 \\
12.63 \\
13.43 \\
17.95 \\
19.10 \\
22.40 \\
25.50 \\
22.35 \\
23.85 \\
23.95 \\
24.50 \\
37.70 \\
38.65 \\
41.00 \\
41.80 \\
42.05 \\
42.35 \\
43.15 \\
44.40 \\
44.95 \\
60.95 \\
62.00 \\
63.00\end{array}$ & 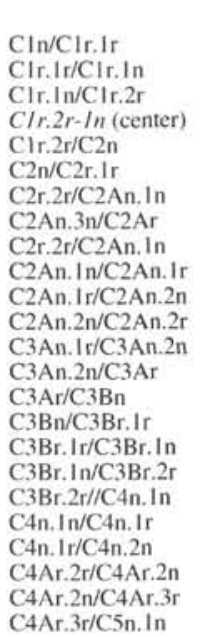 & $\begin{array}{l}0.780 \\
0.984 \\
1.049 \\
1.207 \\
1.757 \\
1.983 \\
2.600 \\
3.553 \\
2.600 \\
3.054 \\
3.127 \\
3.221 \\
6.078 \\
6.376 \\
6.744 \\
6.901 \\
6.946 \\
6.981 \\
7.153-7.245 \\
7.376 \\
7.464 \\
9.428 \\
9.491 \\
9.592\end{array}$ \\
\hline $\begin{array}{l}138-844 \mathrm{C}- \\
2 \mathrm{H}-2,0 \\
2 \mathrm{H}-2,45 \\
2 \mathrm{H}-6,20 \\
2 \mathrm{H}-6,125 \\
3 \mathrm{H}-1,125 \\
3 \mathrm{H}-2,130 \\
3 \mathrm{H}-2,150 \\
3 \mathrm{H}-3,45 \\
3 \mathrm{H}-3,55 \\
3 \mathrm{H}-4,0 \\
3 \mathrm{H}-5,0 \\
3 \mathrm{H}-5,45 \\
3 \mathrm{H}-5,95 \\
3 \mathrm{H}-5,145 \\
3 \mathrm{H}-6,60 \\
3 \mathrm{H}-6,90 \\
3 \mathrm{H}-6,145 \\
4 \mathrm{H}-2,135 \\
4 \mathrm{H}-4,10 \\
4 \mathrm{H}-4,110 \\
4 \mathrm{H}-5,45 \\
4 \mathrm{H}-6,140 \\
4 \mathrm{H}-7,55 \\
5 \mathrm{H}-2,15 \\
5 \mathrm{H}-2,60 \\
5 \mathrm{H}-5,110 \\
6 \mathrm{H}-2,150 \\
6 \mathrm{H}-3,60 \\
6 \mathrm{H}-3,125 \\
6 \mathrm{H}-4,65 \\
6 \mathrm{H}-5,85 \\
6 \mathrm{H}-6,70 \\
6 \mathrm{H}-6,115 \\
7 \mathrm{H}-1,30\end{array}$ & $\begin{array}{l}10.60 \\
11.05 \\
16.80 \\
17.85 \\
19.85 \\
21.40 \\
21.60 \\
22.05 \\
22.15 \\
23.10 \\
24.60 \\
25.05 \\
25.55 \\
26.05 \\
26.70 \\
27.00 \\
27.55 \\
30.95 \\
32.70 \\
33.70 \\
34.55 \\
37.00 \\
37.65 \\
39.25 \\
39.70 \\
44.70 \\
50.10 \\
50.70 \\
51.35 \\
52.25 \\
53.95 \\
55.30 \\
55.75 \\
56.90\end{array}$ & $\begin{array}{l}11.90 \\
12.35 \\
18.10 \\
19.15 \\
22.20 \\
23.75 \\
23.95 \\
24.40 \\
24.50 \\
25.45 \\
26.95 \\
27.40 \\
27.90 \\
28.40 \\
29.05 \\
29.35 \\
29.90 \\
35.10 \\
36.85 \\
37.85 \\
38.70 \\
41.15 \\
41.80 \\
44.50 \\
44.95 \\
49.95 \\
56.75 \\
57.35 \\
58.00 \\
58.90 \\
60.60 \\
61.95 \\
62.40 \\
64.55\end{array}$ & 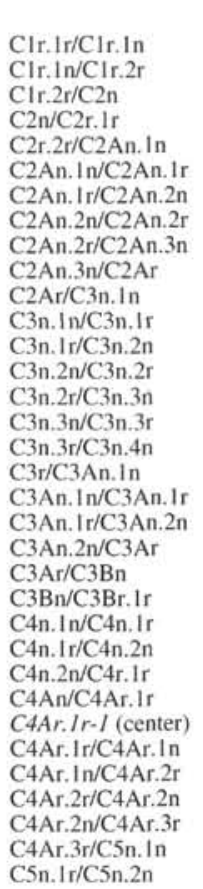 & $\begin{array}{l}0.984 \\
1.049 \\
1.757 \\
1.983 \\
2.600 \\
3.054 \\
3.127 \\
3.221 \\
3.325 \\
3.553 \\
4.033 \\
4.134 \\
4.265 \\
4.432 \\
4.611 \\
4.694 \\
4.812 \\
5.705 \\
5.946 \\
6.078 \\
6.376 \\
6.744 \\
6.901 \\
7.376 \\
7.464 \\
7.892 \\
8.861 \\
- \\
9.069 \\
9.149 \\
9.428 \\
9.491 \\
9.592 \\
9.777\end{array}$ \\
\hline $\begin{array}{l}138-844 \mathrm{D}- \\
1 \mathrm{H}-1,45 \\
1 \mathrm{H}-1,65 \\
1 \mathrm{H}-1,120 \\
1 \mathrm{H}-2,110 \\
1 \mathrm{H}-5,20 \\
1 \mathrm{H}-6,75 \\
1 \mathrm{H}-7,20\end{array}$ & $\begin{array}{l}24.24 \\
24.65 \\
25.20 \\
26.60 \\
30.20 \\
32.25 \\
33.20\end{array}$ & $\begin{array}{l}28.94 \\
29.35 \\
29.90 \\
31.30 \\
34.90 \\
36.95 \\
37.90\end{array}$ & 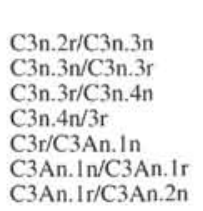 & $\begin{array}{l}4.611 \\
4.694 \\
4.812 \\
5.046 \\
5.705 \\
5.946 \\
6.078\end{array}$ \\
\hline
\end{tabular}

Note: Interval given was measured at the level nearest the reversal. Associated errors are normally \pm 10 to $15 \mathrm{~cm}$. The magnetic polarity time scale and nomenclature are from Cande and Kent (1992). Italics denote cryptochrons identified by Cande and Kent or by this study. 


\section{REFERENCES}

Backman, J., Schneider, D.A., Rio, D., and Okada, H., 1990. Neogene lowlatitude magnetostratigraphy from Site 710 and revised age estimates of Miocene nannofossil datum events. In Duncan, R.A., Backman, J., Peterson, L.C., et al., Proc. ODP, Sci. Results, 115: College Station, TX (Ocean Drilling Program), 271-276.

Berggren, W.A., Kent, D.V., and Van Couvering, J.A., 1985. The Neogene: Part 2. Neogene geochronology and chronostratigraphy. In Snelling, N.J. (Ed.), The Chronology of the Geological Record. Geol. Soc. London Mem., 10:211-260.

Blakely, R.J., 1974. Geomagnetic reversals and crustal spreading rates during the Miocene. J. Geophys. Res., 79:2979-2985.

Cande, S.C., and Kent, D.V., 1992. A new geomagnetic polarity time scale for the Late Cretaceous and Cenozoic. J. Geophys. Res., 97:13917-13951.

Cox, A., and Engebretson, D., 1985. Changes in motion of the Pacific plate at 5 Myr BP. Nature, 313:472-474.

Demarest, H.H., 1983. Error analysis for the determination of tectonic rotation from paleomagnetic data. J. Geophys. Res., 88:4321-4328.

Hagelberg, T., Shackleton, N., Pisias, N., and Shipboard Scientific Party, 1992. Development of composite depth sections for Sites 844 through 854. In Mayer, L., Pisias, N., Janecek, T., et al., Proc. ODP, Init. Repts., 138 (Pt. 1): College Station, TX (Ocean Drilling Program), 79-85.

Harland, W.B., Armstrong, R.L., Cox, A.V., Craig, L.E., Smith, A.G., and Smith, D.G., 1990. A Geologic Time Scale 1989: Cambridge (Cambridge Univ. Press).

Harrison, C.G.A., 1974. The paleomagnetic record from deep-sea sediment cores. Earth Sci. Rev., 10:1-36.

Heirtzler, J.R., Dickson, G.O., Herron, E.M., Pitman, W.C., and Le Pichon, X. 1968. Marine magnetic anomalies, geomagnetic field reversals, and motions of the ocean floor and continents. J. Geophys. Res., 73:2119-2136.

King, J.W., Banerjee, S.K., and Marvin, J., 1983. A new rock-magnetic approach to selecting sediments for geomagnetic paleointensity studies: application to paleointensity for the last 4000 years. J. Geophys. Res. 88:5911-5921.
Kirschvink, J.L., 1980. The least-squares line and plane and analysis of palaeomagnetic data. Geophys. J. R. Astron. Soc., 62:699-718.

Klitgord, K.D., and Mammerickx, J., 1982. Northern East Pacific Rise: magnetic anomaly and bathymetric framework. J. Geophys. Res., 87:67256750 .

LaBrecque, J.L., Kent, D.V., and Cande, S.C., 1977. Revised magnetic polarity time scale for Late Cretaceous and Cenozoic time. Geology, 5:330-335.

Mayer, L., Pisias, N., Janecek, T., et al., 1992. Proc. ODP, Init. Repts., 138 (Pts. 1 and 2): College Station, TX (Ocean Drilling Program).

McFadden, P.L., and Reid, A.B., 1982. Analysis of paleomagnetic inclination data. Geophys. J. R. Astron. Soc., 69:307-319.

Minster, J.B., and Jordan, T.H., 1978. Present-day plate motions. J. Geophys. Res., 83:5331-5354.

Ness, G., Levi, S., and Couch, R., 1980. Marine magnetic anomaly time scales for the Cenozoic and Late Cretaceous: a precis, critique, and synthesis. Rev. Geophys. Space Phys., 18:735-770.

Opdyke, N.D., 1972. Paleomagnetism of deep-sea cores. Rev. Geophys. Space Phys., 10:213-249.

Schneider, D.A., and Kent, D.V., 1990. Paleomagnetism of Leg 115 sediments: implications for Neogene magnetostratigraphy and paleolatitude of the Réunion hotspot. In Duncan, R.A., Backman, J., Peterson, L.C., et al., Proc. ODP, Sci. Results, 115: College Station, TX (Ocean Drilling Program), 717-736.

Abbreviations for names of organizations and publication titles in ODP reference lists follow the style given in Chemical Abstracts Senvice Source Index (published by American Chemical Society).

Date of initial receipt: 3 November 1993

Date of acceptance: 21 May 1993

Ms 138SR-105

Table 5. Paleolatitude estimates from selected cores.

\begin{tabular}{|c|c|c|c|c|c|c|c|c|}
\hline \multirow[b]{2}{*}{ Core } & \multirow{2}{*}{$\begin{array}{c}\text { Nominal age } \\
\text { (Ma) }\end{array}$} & \multicolumn{3}{|c|}{ Inclination } & \multirow[b]{2}{*}{$n$} & \multirow[b]{2}{*}{$\alpha 95$} & \multirow{2}{*}{$\begin{array}{c}\text { pLat } \\
\text { (pmag) }\end{array}$} & \multirow{2}{*}{$\begin{array}{c}\text { pLat } \\
\text { (hot spot) }\end{array}$} \\
\hline & & (N) & (R) & ( $\mathrm{N}$ and $\mathrm{R}$ ) & & & & \\
\hline \multicolumn{9}{|l|}{ Site 845} \\
\hline $845 \mathrm{~B}-10 \mathrm{H}$ & 7.0 & \multirow{2}{*}{$7.9^{\circ}$} & 18.5 & $12.1^{\circ}$ & $3^{2}$ & 3.3 & $7.7^{\circ} \pm 1.3$ & $6.7^{\circ}$ \\
\hline $845 \mathrm{~A}-11 \mathrm{H}$ & 7.3 & & $\underset{0}{15.8}$ & $13.2^{\circ}$ & 1 & 3,3 & $6.5^{\circ} \pm 1.3$ & $6.6^{\circ}$ \\
\hline $845 \mathrm{~B}-14 \mathrm{H}$ & 9.6 & $3.0^{\circ}$ & $8.7^{\circ}$ & $4.0^{\circ}$ & ${ }^{2}$ & 4.4 & $3.4^{\circ} \pm 1.8$ & $5.9^{\circ}$ \\
\hline $\begin{array}{l}\text { Site } 854 \\
854 \mathrm{~B}-3 \mathrm{H}\end{array}$ & 6.9 & 15.1 & 25.8 & $20.0^{\circ}$ & $0^{2}$ & 4.2 & $\begin{array}{c}10.3^{\circ} \pm 1 \\
7^{\circ}\end{array}$ & $9.9^{\circ}$ \\
\hline $854 \mathrm{C}-4 \mathrm{H}$ & 7.2 & 12.5 & 22.1 & $18.0^{\circ}$ & $4^{1}$ & 5.2 & $9.2^{\circ} \pm 2.1$ & $9.8^{\circ}$ \\
\hline $854 \mathrm{C}-6 \mathrm{H}$ & 9.0 & 19.1 & 23.7 & $21.1^{\circ}$ & $2^{3}$ & 4.3 & $\begin{array}{c}10.9^{\circ} \pm 1 \\
7^{\circ}\end{array}$ & $9.5^{\circ}$ \\
\hline
\end{tabular}

Note: The high-coercivity directions are separated into normal $(N)$, reverse $(R)$ and combined ( $\mathrm{R}$ and $\mathrm{N}$ ) polarity groups (those directions that appear to be transitional have been excluded from all groups). The paleolatitude estimate, pLat(pmag), was determined from the combined ( $\mathrm{N}$ and $\mathrm{R}$ ) inclination measurements. The estimate, pLat(hot spot), was calculated using the Pacific-Hot Spot rotation parameters of Cox and Engebretson (1985): $61.84^{\circ} \mathrm{N}, 82.53^{\circ} \mathrm{W}, 4.83^{\circ}\left(5 \mathrm{Ma}\right.$ reconstruction); $69.2^{\circ} \mathrm{N}, 74.0^{\circ} \mathrm{W}, 9.7^{\circ}(9.8 \mathrm{Ma}$ reconstruction). When reconstructing the paleolatitude of Site 845 , one also assumes that all motion relative to the Pacific Plate can be removed by extrapolating with the Cocos-Pacific rotation parameters of Minster and Jordan (1978): $38,72^{\circ} \mathrm{N}, 107.39^{\circ} \mathrm{W}$, $2.208 \%$ m.y. Paleomagnetic results for Site 845 have been corrected for nonvertical penetration of the corer using measurements of hole drift from the photographic orientations tool (no orientation data were collected for Site 854). Averages of the inclination-only paleomagnetic data employ the maximum likelihood technique of McFadden and Reid (1982), using their Equation 40 with the hatted value of $\theta$ so that each of the averages is slightly steeper than the arithmetic average. This technique also can generate an estimate of the Fisher precision parameter $\kappa$ from which an $\alpha 95$ is calculated according to the number of sample values included. At the near-equatorial latitude of the sites, the 2- $\sigma$ error on paleolatitude has been taken as being equal to the $1-\sigma$ error on inclination. This was estimated by taking one-half of $\alpha 95$ and multiplying by a correction factor of 0.8 (Demarest, 1983) so as not to overestimate the one-dimensional error. 